\title{
Age-related Differences in the Effects of Working Memory Capacity and Cognitive Load on Word Recognition: An Eye Tracking Study
}

\author{
Min Ah Yoo ${ }^{a}$, Seung Ha Oh${ }^{b}$, Jeong Sug Kyongc, Jee Eun Sunga \\ ${ }^{a}$ Department of Communication Disorder, Ewha Womans University, Seoul, Korea \\ ${ }^{b}$ Department of Otorhinolaryngology-Head and Neck Surgery, Seoul National University Hospital, Seoul National University College of Medicine, \\ Seoul, Korea \\ 'Department of Audiology and Speech-Language Pathology, Hallym University of Graduate Studies, Seoul, Korea
}

\author{
Correspondence: Jee Eun Sung, $\mathrm{PhD}$ \\ Department of Communication Disorders, Ewha \\ Womans University, 52 Ewhayeodae-gil, \\ Seodaemun-gu, Seoul 03760, Korea \\ Tel: $+82-2-3277-2208$ \\ Fax: +82-2-3277-2122 \\ E-mail: jeesung@ewha.ac.kr
}

Received: January 5, 2021

Revised: February 4, 2021

Accepted: February 4, 2021

This work was supported by the Ministry of Education of the Republic of Korea and National Research Foundation of Korea (NRF-2019R1A2C1089280).

\begin{abstract}
Objectives: The purpose of the study was to identify the impact of age-related working memory capacity and cognitive load to word recognition using an eye tracker. Methods: A total of 48 participants (24 young, 24 elderly adults) who were divided according to working memory capacity (high, low) participated in the study. This study consisted of a digit load and word recognition task. Results: First, the elderly group had lower accuracy and slower response times than the young group. There was a significant difference between working memory capacity and cognitive load in response time. In the group with low working memory capacity, the response time increased under lower cognitive load, which was different from the group with a high working memory capacity. Next, the elderly group had a lower proportion of fixation than the young group by time interval. In addition, there was a significant interaction between group and cognitive load by time interval. In particular, the proportion of fixation decreased over time under a high cognitive load while the proportion of fixation increased under a low cognitive load in the elders, because the inhibition and switching abilities were weakened which made the elders unable to process information efficiently. Conclusion: The study results showed significant effects between working memory capacity and cognitive load in response time and proportion of fixation. This implies that complex factors influence language processing, which makes measuring accuracy insufficient. Thus, this research confirms the correlation among aging, working memory, and cognitive load through both online and offline measurement.
\end{abstract}

Keywords:Working memory capacity, Cognitive load, Aging, Word recognition, Eye tracking
통계청에 의하면 한국의 65세 이상 고령 인구 비중이 2019년 $14.9 \%$ 에서 2067년 46.5\%까지 빠른 속도로 증가할 것이라고 밝혔 다. 특히, 2045년에는 우리나라가 전 세계적으로 고령 인구 비중이 가장 높은 국가가 될 것으로 예측하였다. 가속화되는 고령화 현상 으로 인해 노인에 관한 관심이 증가하였고, 노화 및 노인 언어능력 에 관한 연구가 점점 많아지고 있다(Yang, Lee, \& Park, 2020). 노인 의 단어 재인에 관한 연구들을 살펴보면, 노화가 복합적인 언어처 리과정에 미치는 영향에 대해 의견이 분분하다. 먼저, 청년보다 노 인이 단어 또는 문장 재인 속도나 읽기 속도가 저하된다는 결과가
다수 존재한다(Balota \& Duchek, 1988; Howard, Shaw, \& Heisey, 1986; Sass, Legge, \& Lee, 2006). 이와는 달리, 노화가 되어도 어휘 적 지식이 지속적으로 축적되어 오히려 증가된다는 결과도 존재한 다(Burke \& Peters, 1986; Jeong \& Pyun, 2005; Spieler \& Balota, 2000). 해당 연구자들에 따르면, 단어 이해 과정에서는 청년과 노년 집단의 수행 수준이 크게 다르지 않음을 보여주었다(Bayles, Tomoeda, Kaszniak, Stern, \& Eagans, 1985). 또한, Giaquinto, Ranghi 와 Butler (2007)의 연구는 사건관련전위(Event Related Potential, ERP) 실험을 통해 단어들을 들려주고 목표 단어를 들을 때마다 반 
응해야 하는 과제를 시행하였다. 연구결과, 청년과 노년 집단에서 언어의 의미적 처리를 반영하는 $\mathrm{N} 400$ 의 진폭, 시작 지연 시간 및 지 속 시간에 유의한 차이가 없었음을 밝혔다.

노화로 인해 주의력, 기억력, 추론 등 여러 인지적 요소의 문제도 언어처리의 어려움과 관계가 있다(Lee \& Kim, 2012; Lee, Kim, Lee, Chung, \& Park, 2012; Salthouse \& Babcock, 1991; Thornton \& Light, 2006; Yoo, Lee, \& Do, 2005). 특히, 여러 인지적 요소 중 작업 기억(working memory)은 문제해결, 추론, 언어이해 등과 같이 고 차원적이고 복잡한 인지처리에서 중요한 역할을 한다는 점에서 꾸 준히 주목받았다(Caplan, DeDe, Waters, Michaud, \& Tripodis, 2011; Caplan \& Waters, 1999; Miyake, Just, \& Carpenter, 1994; DeDe, Caplan, Kemtes, \& Waters, 2004; Kim, Sung, \& Kim, 2013; Lee, Lee, Song, \& Kim, 2014; Montgomery \& Evans, 2009; Caplan $\&$ Waters, 2005). 작업기억은 일시적으로 정보를 저장하고 처리하 는 공간으로 제한된 용량(limited capacity)을 가지고 있으며, 작업 기억용량(working memory capacity)은 노화에 의해 감소한다고 알려져 있다(Daneman \& Merikle, 1996; Hultsch, Hertzog, \& Dixon, 1990). 그러나 노화에 따른 작업기억용량에 관해 상반된 의견 도 존재한다(Salthouse, 1990; Salthouse \& Babcock, 1991). 작업기 억용량 감소는 노화뿐 아니라 유전적 요인, 신체적 요인, 교육수준 같은 요인에 의해 개인마다 다르다는 의견이다. 작업기억 과제의 수 행률은 과제가 복잡하거나 정보의 조작을 요구하는 경우처럼 작업 기억 부담이 큰 조건에서 감퇴가 크게 나타난다. 반면, 문법 요소와 같은 자동화된 문장처리에는 노화에 따른 작업기억용량 감소가 끼 치는 영향이 최소화된다고 보고되고 있다(Waters \& Caplan, 2001; Caplan \& Waters, 2005).

Baddeley (2000)에 의하면, 작업기억은 단기적으로 입력된 언어 정보들을 주로 저장하는 음운루프(phonological loop), 언어 이외 에 시공간적인 정보들을 주로 처리하는 시공간 잡기장(visuo-spatial sketch pad), 두 가지 기제를 모두 관리하는 중앙집행기(central executive), 시공간 잡기장 영역으로부터 정보를 통합하며 임시 저 장소 역할을 담당하는 일화적 완충기(episodic buffer)로 구성되었 다(Baddeley, 2000). 세부적으로 음운루프와 시공간 잡기장 영역 은 상대적으로 단순한 정보를 담당하지만, 중앙집행기는 비교적 고차원의 정보를 담당하고 언어의 이해와 추론에도 관여한다. 또 한, 장기기억에 저장된 정보 중, 필요한 정보만을 선택하여 인출하 고 관련이 없는 정보는 인출하지 못하도록 억제하는 역할을 하기도 한다. 더불어 일화적 완충기는 장기기억과 연결고리를 가진 영역으 로 음운정보와 시각정보가 동시에 제시되는 상황에서 정보를 통합 하는 역할을 한다. 이처럼 일화적 완충기를 통해 연결되어 있기는
하지만, 엄연히 작업기억이 장기기억과 분리되어 있고, 중앙집행기 와 저장을 담당하는 다른 영역으로 구성되어 있다고 보았다. 이후, 작업기억의 핵심요인으로 중앙집행기 기능이 주목받으면서 작업기 억의 통제처리나 개인차에 관한 연구들이 나타났다. 그 중, Just와 Carpenter (1992)는 작업기억용량 이론(working memory capacity theory)을 통해 작업기억용량이 개인마다 다르며 한정되어 있다고 보았다. 따라서 개인이 보유한 작업기억용량보다 인지적으로 부담 이 많은 과제를 수행 또는 저장과 처리의 기능을 동시에 수행할 경 우, 자원을 과도하게 소모하게 된다고 보았다. 이로 인해 다른 과제 를 수행할 자원이 부족하게 되고 수행의 정확성 또는 효율 저하로 나타난다고 주장하였다.

작업기억용량의 개인차에 대한 이론은 크게 자원 공유 모델 (shared recourse model)과 억제기반 자원 모델(inhibition based model)로 구분할 수 있다. 먼저, 자원 공유 모델을 주장하는 Carpenter와 Just (1989)는 작업기억의 저장과 처리의 영역을 따로 세분 화하지 않고 작업기억의 일원화를 가정하고 있다. 작업기억 자원은 처리와 저장 두 가지 요구에 직면하게 되고, 처리가 수월한 경우, 처 리 요구보다 더 적은 자원을 사용하여 저장 요구에 더 많은 자원을 사용할 수 있다. 또한, 필요에 따라 저장과 처리 과정에서 작업기억 자원을 효율적으로 사용한다고 보았다. 억제기반 자원 모델을 주 장하는 Hasher와 Zacks (1988)는 작업기억용량의 개인차는 저장 과 처리 과정에서 필요하지 않은 자극에 대해 주어진 용량을 사용 하지 않는 억제 기제의 차이로 인해 발생하였다고 보았다. 즉, 작업 기억의 영역을 세부적으로 구분하여 제시된 정보의 저장 또는 처 리 과정에서 관련성이 없거나 불필요한 정보를 억제하는 개인의 능 력이 더 중요하다고 주장하였다. 이를 기반으로 다양한 연구에서 노화에 따른 작업기억용량 저하를 용량 자체 차이보다는 개별적 자원 영역의 억제 기제로 설명하였으며, 연령과 상관없이 작업기억 용량에서의 개인차는 억제능력과 관계있음을 보여주었다(Conway \& Engle, 1994; Conway, Tuholski, Schisler, \& Engle, 1999). 덧 붙여, 작업기억에 있어서 Caplan과 Waters (1999)는 개별 자원 모 델(separated resource model)을 주장하였다. 작업기억이 하나의 인지 자원으로 구성되어 있다는 Just와 Carpenter (1992)의 자원 공유 모델과 달리, 인지 자원은 개별적으로 이루어져 있다고 보았 다. 따라서 언어처리 과정에서 저장과 처리기능에 사용되는 인지 자원은 일반적인 작업기억 과제로 측정되는 것과는 다르다고 주장 하였다.

이에 작업기억과 언어처리에 관련된 국내외 연구를 살펴본 결과, Lee (2005)는 20대부터 80대까지 성인을 대상으로 하여 한국판 기 억평가척도(Korean version of Memory Assessment Scales; Lee, 
Ahn, \& Jung, 1999) 수행을 비교하였으며, 노년 집단이 다른 집단 에 비해 작업기억 과제에서 수행이 낮았음을 보여주었다. 해당 연 구를 통해 단기기억 과제보다 작업기억 과제가 노화에 따른 손상 이 더 민감함을 밝혔다. 또한, Eom, Oh와 Sung (2016)은 실어증 환 자와 정상 노년 집단을 대상으로 작업기억 과제 유형에 따른 수행 력을 분석한 결과, 4 가지 과제 중에서도 숫자 바로 및 거꾸로 따라 지시하기 과제가 실어증 중증도와 유의한 상관관계가 있음을 밝혔 다. 이를 통해 작업기억 과제 수행력은 자극 유형, 반응 순서에 따라 차이가 있음을 시사하였다. Nitsan, Wingfield, Lavie와 Ben-David (2019)의 연구는 청년 집단을 대상으로 작업기억용량 차이에 따라 집단을 구분한 후, 이중 과제(dual task)를 통해 작업기억용량에 따 라 어휘처리에 미치는 영향에 대해 살펴보았다. 연구 결과, 작업기 억용량 차이에 따라 집단 간 반응정확도에는 큰 차이가 없었으나, 낮은 작업기억용량을 가진 집단에서 시선고정비율이 낮았음을 보 여주었다. 이를 통해작업기억용량이 단어 재인에 있어서 중요한 변 수임을 주장하였다.

단어 재인과 작업기억의 상관성에 관한 연구는 실시간 시선추적 분석 방법을 통해 더 다양한 결과를 얻을 수 있다. 시선추적은 연구 대상자가 어디에 주의 집중을 하는지 명확하게 알려준다(Bolden, Barmby, Raine, \& Gardner, 2015). 기존 연구에서 실험 이후, 연구 대상자의 응답에 대해서만 분석하였던 것과 달리, 실험 상황에서 발생할 수 있는 기억의 변형이나 왜곡 영향을 최소화하여 실시간 으로 대상자의 반응을 분석할 수 있다(Huang \& Chen, 2015; Susac, Bubic, Kaponja, Planinic, \& Palmovic, 2014). 이에 시선추적에서 활용하는 시각적 자극이 작업기억에 관여하는지를 알아보는 연구 가 진행되었으며, 이에 대해 다양한 의견이 존재한다. 우선 작업기 억의 가용한 저장용량은 시각탐색에 직접적인 영향을 준다는 견해 가 존재한다. 즉, 시각적으로 제시된 모든 목표자극과 방해자극은 반드시 시각 작업기억으로 저장된다고 보았다(Bundesen, 1990; Duncan \& Humphreys, 1989; Treisman \& Gelade, 1980). 반면, 작 업기억이 시각탐색에 직접적인 영향을 주는 것은 아니라는 의견도 존재한다. Tark과 Kim (2005a,b)은 공간적, 시각적, 집행적 작업기 억으로 나누어 시각적 자극과의 상관성에 대해 살펴보았다. 실험 1 은 시각적으로 제시되는 목표자극의 개수가 증가하는 비공간적 시 각 작업기억 과제, 실험 2는 제시되는 목표자극의 위치에 대한 공간 적 작업기억 과제, 실험 3 은 제시되는 네 개의 알파벳을 순서대로 재배열을 한 후, 목표자극을 선택하는 집행적 작업기억 과제를 실 시하였다. 실험 결과, 해당 연구에서의 시각적 자극은 인지적 자원 을 요구할 만큼 어려운 과제가 아니었으며, 시각적 처리는 낮은 수 준의 정보처리과정에서 일어나는 것으로 상대적으로 상위 수준의
처리 기제인 작업기억의 영향을 받지 않는 것으로 해석하였다. 즉, 시각적 표시가 작업기억과 관련된 인지 자원을 소모하지 않음을 나 타냈다. 해당 선행연구는 오프라인 측정 과정에서는 작업기억용량 이 영향을 미치지만, 온라인 실시간 처리과정에서는 시각적 자극은 인지 자원의 개입이 최소화되기 때문에 자극에 대한 작업기억 측정 에 있어서 결과가 다를 수 있다는 개별 자원 모델(separate resource model) (Caplan \& Waters, 1999) 주장을 뒷받침하였다.

더 나아가 단어 재인과 인지부하 및 작업기억용량의 연관성은 시 선추적을 통해 확인이 가능하다. 구체적으로 인지부하 정도에 따 라 중뇌의 배측주위신경망, 청반부신수질호르몬, 대상엽의 영역과 전두엽(frontal cortex)과 전전두엽(pre-frontalcortex) 사이의 하향 식 처리방식(top-down control)이 활성화되고 이는 정보처리과정 에서 동공크기 변화에 영향을 미친다(Buckner, 2013; Geva, Zivan, Warsha, \& Olchik, 2013; Park \& Whang, 2018; Van Steenbergen \& Band, 2013). 따라서 눈의 움직임에 따라 인지부하 정도를 확인할 수 있다. 뿐만 아니라, 작업기억용량도 뇌의 신경회로망 간 상호작 용을 통해 활성화되는 눈의 움직임과 연관성이 있다고 알려져 있다 (Johnson \& Raye, 1998; Parker, Relph \& Dagnall, 2008). 또한, 시선 추적기법은 비침습적이고 실험 자극에 따라 조작이 자유로우며, 최 대한 자연스러운 언어처리과정을 관찰할 수 있다는 장점이 있다. 따 라서 시선추적기법을 통해 언어처리과정을 분석하는 연구들이 오 래전부터 활발하게 진행되었다(Clifton et al., 2016; Rayner, 1998, 2009). 국내에서 노년 집단의 언어처리에 관한 시선추적 연구를 확 인한 결과, Jo와 Sung (2019) 연구에서는 시선추적을 통해 단어 재 인 과제에서 방해자극 유형에 따라 청년과 노년 집단 간 수행 결과 에 대해 반응정확도, 반응시간, 시선고정비율을 분석하여 집단 간 수행 차이가 있음을 밝혔다. 또한, 본 연구에서는 앞서 제시된 Nit$\operatorname{san}$ 등(2019)의 선행연구를 활용하여 청년과 노년을 대상으로 인지 부하 조건에서 작업기억용량차이에 따라 단어 재인에 미치는 영향 을 확인하고자 하였다. 단어 재인 능력을 확인하는 방법은 두가지 로 구분되며, 첫 번째는 과제가 끝난 후, 대상자의 반응을 통해서 확 인하는 방법(offline)으로 반응정확도, 반응시간이 대표적이다. 두 번째는 과제가 제시되는 동안 실시간으로 대상자 반응을 살펴보는 방법(online)으로 시선추적이 대표적이다. 오프라인 변수는 과제 이후의 대상자 반응을 통해 처리 및 이해 과정의 결과물을 보여줄 뿐이며, 과제를 수행하는 과정에서 대상자의 실시간 반응을 확인 할 수 없기 때문에 온라인과 오프라인 처리 과정을 동시에 측정할 필요가 있다(Thompson \& Choy, 2009; Wassenaar \& Haggort, 2007). 더 나아가 현재까지 한국에는 성인을 대상으로 작업기억용 량과 언어처리와의 관련성에 대해 단어 재인 수준에서 온라인 및 
오프라인 측정 결과를 비교, 분석한 연구는 아직 미비한 실정이다. 따라서 본 연구는 청년과 노년 집단을 대상으로 작업기억용량, 인 지부하에 따른 단어 재인 정확도, 반응시간 및 시선고정비율에서 차이를 보이는지 시선추적기법을 통해 알아보고자 하였다. 구체적 인 연구 질문은 아래와같다.

첫째, 단어 재인 과제에서 인지부하 조건(고, 저) 및 작업기억용 량(고, 저)에 따라 청년 및 노년 집단 간 반응정확도에 유의한 차이 가 있는가?

둘째, 단어 재인 과제에서 인지부하 조건(고, 저) 및 작업기억용 량(고, 저)에 따라 청년 및 노년 집단 간 반응시간에 유의한 차이가 있는가?

셋째, 단어 재인 과제에서 인지부하 조건(고, 저) 및 작업기억용 량(고, 저)에 따라 청년 및 노년 집단 간 시간 구간에 따른 목표자극 시선고정비율에 유의한 차이가 있는가?

\section{연구방법}

\section{연구대상}

본 연구는 서울 및 인천, 경기 지역에 거주하는 청년층(만 19-39 세) 24명과 노년층(만 60-79세) 24명, 총 48명을 대상으로 실시하였 다. 대상자들은 사전에 본 연구에 대한 상세한 안내를 충분히 듣고 서면으로 연구 참여에 동의하였다. 본 연구는 생명윤리위원회의 승 인을 받아 진행되었다(ewha-202008-0015-01).

두 집단은 모두 (1) 한국어가 모국어인 자, (2) 건강선별기준 (Christensen, Multhaup, Nordstrom, \& Voss, 1991)에 근거하여 신 경학적 또는 정신적인 병력이나 두뇌 손상 병력이 보고되지 않은 자이어야 하며, (3) 언어 및 인지적 신경학적 손상, 발달적 병력이 보 고되지 않은 자, (4) 한국판 간이정신상태검사(Korean-Mini Mental State Examination; Kang, $\mathrm{Na}, \& \mathrm{Hahn}, 1997)$ 점수가 연령 및 교 육년수에 비해 $16 \%$ ile 이상으로 정상 범위에 해당하는 자(Kang, 2006)를 말한다. 또한, (5) 자가보고 및 선별검사 과정을 통해 과제 를 수행하는 데 필요한 청각 및 시각능력에 문제가 없는 자이어야 한다. 더 나아가 (6) 중이 병변에 질환이 없는 자, (7) 폐소공포증이 없는 자이며, (8) 자가보고를 통해 일상생활능력을 유지하면서 독 립적으로 생활할 수 있는 자를 선정하였다. 추가로 노년층에게는 (1) 언어기억검사(Seoul Verbal Learning Test, SVLT; Kang \& Na, 2003)를 실시하여 점수가 연령 및 교육년수에 비해 $16 \%$ ile 이상의 정상 범주에 해당하는 자, (2) 노인 우울척도 단축형(Korean version of the short form of Geriatric Depression Scale, SGDS-K; Cho et al., 1999) 검사에서 8점 이하로 우울증이 없는 자를 선별하였다.
또한, 모든 대상자는 청력검사를 시행하였다. 청년 집단의 경우, (1) 순음청력역치가 $500,1,000,2,000,4,000 \mathrm{~Hz}$ 의 평균이 $20 \mathrm{~dB}$ 이 하인 자(Humes, 2020)이며, (2) 한국표준 단음절어표인 KS-MWL 중 일반용(KS-MWL-A)을 활용하여 쾌적역치(Most Comfortable Listening, MCL) 수준에서 어음청력검사 결과가 $90 \%$ 이상의 어음 인지도를 가진 자(Joo \& Jang, 2009)로 선별하였다. 노년 집단의 경 우, Humes (2020) 연구를 참고하여 연령별로 다른 청력 기준을 적 용하여 선별하였다. 연령별로 (1) 60 대인 경우, $250,500,1,000,2,000$, $4,000 \mathrm{~Hz}$ 에서 $20 \mathrm{~dB}$ 이하이며, $8,000 \mathrm{~Hz}$ 에서 $30 \mathrm{~dB}$ 이하인 자, (2) 70 대인 경우, $250,500,1,000,2,000 \mathrm{~Hz}$ 에서 $20 \mathrm{~dB}$ 이하, $4,000 \mathrm{~Hz}$ 에 서 $30 \mathrm{~dB}$ 이하, $8,000 \mathrm{~Hz}$ 에서 $50 \mathrm{~dB}$ 이하인 자, (3) 80 대인 경우, 250 , $500,1,000 \mathrm{~Hz}$ 에서 $20 \mathrm{~dB}$ 이하, $2,000 \mathrm{~Hz}$ 에서 $30 \mathrm{~dB}$ 이하, $4,000 \mathrm{~Hz}$ 에서 $50 \mathrm{~dB}$ 이하, $8,000 \mathrm{~Hz}$ 에서 $80 \mathrm{~dB}$ 이하인 자로 선별하였다. 또 한, 한국표준 단음절어표인 KS-MWL 중 일반용(KS-MWL-A)을 활용하여 쾌적역치(Most Comfortable Listening, MCL) 수준에서 어음청력검사 결과가 $90 \%$ 이상의 어음인지도를 가진 자(Joo \& Jang, 2009)를 대상으로 하였다. 추가로 대상자 선정 기준을 충족 하는 총 48 명(청년 24명, 노년 24명)을 대상으로 각 집단 내에서 작 업기억용량(고, 저)으로 다시 분류하였다. 작업기억용량에 따라 고, 저 집단으로 분류하기 위해 (1) 숫자 바로 지시하기와, (2) 숫자 거꾸 로 지시하기(K-WAIS; Hwang, Kim, Park, Choi, \& Hong, 2012), (3) 단어 바로 지시하기와, (4) 단어 거꾸로 지시하기 과제(Sung, 2011) 를 따라 말하기(recall)로 전환하여 시행하였다. 해당 과제에 사용 되는 숫자 또는 단어는 구체적으로 power point 2016으로 맑은고 딕체, 글씨 크기 200으로 작성한 숫자 또는 단어를 자동적으로 1초 에 1 개의 그림이 보이도록 설정하여 모든 대상자에게 해당 과제를 실시하였다. 이렇게 실시한 4 개 과제의 합계 점수를 작업기억용량 을 나타내는 지표로 활용하였으며, 중앙값 분리(median-split)방법 을 사용하였다(Stark, Mandl, Gruber, \& Renkl, 2002). 전체 대상자 의 작업기억 과제 합계 점수를 나열한 후, 노년 집단은 중앙값(19.5) 을 기준으로 작업기억이 높은 집단 12 명, 작업기억이 낮은 집단 12 명으로 나누었다. 청년 집단도 동일한 방식을 활용하여 중앙값 (31.5)을 기준으로 작업기억이 높은 집단 12 명, 작업기억이 낮은 집 단 12 명으로 나누었다. 집단에 따른 교육년수에 유의한 차이가 있 는지 알아보기 위하여 독립표본 $t$ 검정(independent samples $t$-test) 을 실시하였다. 그 결과, 두 집단 간 교육년수의 차이가 통계적으로 유의하지 않았다 $\left(t_{46)}=.634, p>.05\right)$ 본 연구에 참여한 대상자 정보 는 Table 1과 같다. 
Table 1. Descriptive information on participants

\begin{tabular}{|c|c|c|c|c|c|c|c|}
\hline \multirow{2}{*}{\multicolumn{2}{|c|}{$\frac{\text { Group }}{\text { WM }}$}} & \multicolumn{3}{|c|}{ Young (N=24) } & \multicolumn{3}{|c|}{ Old ( $\mathrm{N}=24)$} \\
\hline & & $\begin{array}{c}\text { High } \\
(\mathrm{N}=12)\end{array}$ & $\begin{array}{c}\text { Low } \\
(\mathrm{N}=12)\end{array}$ & $\begin{array}{c}\text { Total } \\
(\mathrm{N}=24)\end{array}$ & $\begin{array}{l}\text { High } \\
(N=12)\end{array}$ & $\begin{array}{c}\text { Low } \\
(\mathrm{N}=12)\end{array}$ & $\begin{array}{c}\text { Total } \\
(\mathrm{N}=24)\end{array}$ \\
\hline \multicolumn{2}{|c|}{ Gender (male:female) } & $0: 12$ & $4: 8$ & $4: 20$ & $2: 10$ & $4: 8$ & 6:18 \\
\hline \multirow[t]{3}{*}{ Age (yr) } & Mean & 22.92 & 26.17 & 24.54 & 63.42 & 68.50 & 65.96 \\
\hline & (SD) & (3.15) & (6.47) & (5.23) & (3.20) & (3.66) & (4.25) \\
\hline & Range & $20-30$ & $19-38$ & $19-39$ & $60-69$ & $62-74$ & $60-74$ \\
\hline \multirow[t]{3}{*}{ Education (yr) } & Mean & 14.67 & 14.25 & 14.46 & 16.08 & 13.58 & 14.83 \\
\hline & (SD) & (2.31) & (1.22) & (1.82) & (1.08) & (2.47) & (2.26) \\
\hline & Range & $12-18$ & $12-16$ & $12-18$ & 14-18 & $11-18$ & $11-18$ \\
\hline \multirow[t]{3}{*}{ WM (score) } & Mean & 37.83 & 25.33 & 31.58 & 24.92 & 16.92 & 20.92 \\
\hline & (SD) & (4.09) & (4.38) & (7.61) & (4.38) & (1.83) & (5.24) \\
\hline & Range & $32-45$ & $18-31$ & $18-45$ & 20-34 & $14-19$ & $14-34$ \\
\hline
\end{tabular}

WM= Working Memory capacity.

\section{실험자극}

그림자극

Nitsan 등(2019)의 선행연구를 활용하여 이중 과제로 구성되어 있으며, 인지부하 조건과제인 숫자 외우기 과제(Digit recall task), 단어 재인 과제(Word recognition task)로 구성되어 있다. 우선 인 지부하 조건과제의 경우, 난이도에 따라 2 개의 인지부하 조건으로 구성되어 있다. 높은 인지부하 조건(high preload condition)에서는 숫자 4개를 그림으로 제시하며, 낮은 인지부하 조건(low preload condition)에서는 숫자 1 개를 그림으로 제시하였다. 집단 분류를 위해 실시한 작업기억 과제가 1 초당 1 개의 숫자를 제시한 방식을 활용하여 해당 인지부하 조건과제에서도 동일하게 1 초당 1 개의 숫 자를 화면 중앙에 제시되도록 하였다.

단어 재인 과제의 경우, 그림으로 제시되는 단어는 목표단어 40 개, 음운 관련 단어 40 개, 의미 관련 단어 40 개, 무관련 단어 216 개 를 선정하였다. Bae와 Yi (2010)에 의하면, 2-4음절로 구성된 단어 에서는 음절 수 증가에 따른 반응시간의 지연 차이가 통계적으로 유의하지는 않았다고 언급하였다. 따라서 2음절 단어가 한국어 명 사의 전형적 길이이므로 2-3음절로 이루어진 단어를 목표단어로 선정하였다. 또한, 여러 선행연구에 의하면 두운 동일 단어(onset sharing word)에서 각운 동일 단어(rhyme sharing word)보다 시선 고정비율에 차이가 더 크게 나타났다고 한다(Hadar, Skrzypek, Wingfield, \& Ben-David, 2016; Nitsan et al., 2019). 언어에 따라 중 요한 음운 인식 단위가 달라질 수 있으며, 음절 하위구조인 두운, 각 운에 더 민감하게 반응하는 영어와 달리, 한국어에서는 두운, 각운 보다 음절체 자체가 단어 인식에 더 중요한 것으로 나타났다(Kang, 2007). 이에 본 연구에서는 영어와 한국어의 언어적 차이를 고려하 여 음소 대신 첫 음절 동일 단어를 선정하여 자극을 구성하였다. 노
년 집단을 대상으로 한 명사 범주별 본보기 산출 빈도, 의미전형성 및 친숙도 연구(Sung, Mo, Lee, \& Sim, 2014)의 범주별 산출 빈도 및 주관적 친숙도에 따른 어휘 목록을 참고하여 우선순위가 높은 범주 중심으로 5개 범주(교통수단, 옷, 과일, 생활용품, 네발동물) 내에서 목표단어 목록을 선정하되, 국립국어원의 2001년 형태소 구어 말뭉치를 중심으로 정리된 한국어 사용빈도 조사(National Institute of Korean Language, 2015)를 참고하였다. 본 연구에 사용 한 어휘의 빈도수는 평균 78.33이었으며, 더 정확한 실험을 위해 단 어 자극에 따른 그림자극의 타당도를 검증하였다. 이를 위해 정상 성인 28 명에게 본 실험에 사용되는 어휘 자극과 그에 해당하는 그 림을 제시하고 0 점(매우 관련 낮음)부터 4점(매우 관련 높음)까지 그림과 단어 자극의 관련성에 관해 5 점 척도의 평가를 하였다. 평 가 결과, 3점 미만을 받은 문항은 수정 단계를 거쳐 최종적으로 목 표자극과 방해자극 총 336 개를 선정하였다. 실험에 사용한 전체 단 어목록은 Appendix 1에 제시하였다.

\section{청각적 자극}

연습 문항을 포함하여 총 84 개의 음성 자극은 녹음 시, 표본화 주파수와 비트는 $44,100 \mathrm{~Hz}, 16 \mathrm{bit}$ 로 전문적인 여성 성우 목소리로 녹음하였다. 녹음된 음원은 Audacity 프로그램을 통해 편집하였 다. 각 음성 파일의 시작 구간에 묵음(Silence) $1,000 \mathrm{~ms}$ 을 삽입하여 모든 단어 시작(Onset)이 동일하도록 조정하였고, 모든 단어는 1초 동안 제시되도록 하여 끝나는 구간(Offset)도 동일하게 음성파일을 편집하였다.

\section{연구도구}

본 연구는 안구 움직임을 기록하기 위한 시선추적기(Eye-tracker)를 이용하였으며, 본 연구에서는 Eye Link Portable Duo (SR Research Ltd., Ontario, Canada)를 사용하여 자료를 수집하였다. 구 체적으로 해당 기기는 모니터 아래 시선추적장비를 배치하여 대상 자의 시선을 추적하였다. 해당 기기는 머리 고정형(Head Stabilized Tracking) 방식과 원격형(Remote mode Tracking) 방식 모두 가능 하지만, 해당 연구에서는 머리 고정형 방식으로 진행하였다. 시선 추적기와 대상자의 눈 사이 간격을 일정하게 유지하기 위하여 연구 대상자의 얼굴을 고정시킬 수 있는 턱 고정대(chin-rest)를 이용하 였다. 해당 실험에 사용될 시각적, 청각적 자극 배열 및 실험 진행은 SR Research Experiment Builder 2.3.1 [Computer software] (2020)를 활용하여 편집하였으며, 데이터 분석은 SR Research Eye Link Data Viewer 3.2.1 [Computer software] (2018)을 사용하였다. 


\section{연구절차}

해당 연구는 대상자 선정 기준을 충족하는 피험자들을 대상으 로 조용한 조건에서 시선추적 검사를 진행하기 위해 모든 연구 대 상자는 방음 부스에서 실험을 시행하였다. 청각 자극은 연구 대상 자에게 $1 \mathrm{~m}$ 떨어진 채 $+45^{\circ}$ 와 $-45^{\circ}$ 에 위치한 스피커를 통해 대상자 에게 제시하였다. 목표음은 대상자가 '크지도 작지도 않으며, 편하 다’고 느끼는 주관적 쾌적역치(Most Comfortable Listening, MCL) 수준에 맞추어서 제시하였다. 실험 과정에서 청년 집단 중 해당 장 소에 오지 못한 일부는 방음 부스 대신 조용한 개별 공간에서 검사 를 진행하였다. 검사 진행 시에는 안드로이드 소음측정기 어플 Sound Meter (Version 5.6)를 사용하여 미리 측정한 방음 부스 내 주변 소음과 목표음 수준을 고려하여 청각 자극을 제시함으로써 최대한 검사 상황과 유사하게 하여 검사를 실시하였다. 실험의 순 서는 다음과같다.

보정 및 검증 이후, (1) 준비 단계, (2) 인지부하 조건과제 단계, (3) 그림 단서 제시 단계, (4) 준비 단계, (5) 단어 재인 과제 단계, (6) 숫 자 응답 단계로 이루어져 진행되었다. 대상자는 모니터로부터 약 $60 \mathrm{~cm}$ 정도 떨어져 앉고, 우선 시선추적에 문제가 없는지 확인하기 위해 사전 보정 및 검증 작업을 거쳤다. 보정 및 검증 단계(calibration)는 대상자의 시선이 시선추적기가 추적 가능한 각도 범위 내 에 있는지 맞추는 과정으로 시선이 잘 잡히는지 기기의 Auto 모드 로 확인한 후, 다음 단계로 넘어갔다. 보정 이후, 연구자는 대상자에 게 '실험에 참여해 주셔서 감사합니다. (1) 지금 검은 세모()가 있 는 화면이 제시된 후, 바로 숫자를 4 개 또는 1 개 보여드릴 것입니다. 마지막에 해당 숫자들을 질문할 예정이오니, 주의 깊게 보고 기억 해주시길 바랍니다. (2) 화면(+)이 제시된 후, 1 개 단어를 들려드릴 것입니다. 단어를 잘 듣고, 4 개의 그림 중에서 들려드린 단어와 일치 하는 그림을 찾아 버튼을 눌러주시면 됩니다. 마지막으로 (3) 단어 를 선택한 이후에, (O)가 나오면 아까 들려드린 숫자를 기억해서 말 씀해주시면 됩니다. 자, 시작합니다!'라고 과제에 대한 지시를 드렸 다. 이후, 4 개의 연습 문항을 충분히 진행하여 숙지할 수 있도록 한 후, 본 실험을 진행하였다.

구체적으로 본 연구의 절차에 관해 설명하자면, 보정 및 검증 단 계는 검사 시작에 앞서 먼저 실시하였다. 이후에는 검사 중간 주어 지는 4 번의 휴식 시간 이후, 검사를 다시 시작할 때마다 진행하였 다. 휴식 시간은 20 문항마다 주어졌다. (1) 준비 단계는 인지부하 조 건과제가 제시되기 전 ' $\mathbf{\wedge}$ '응시점(fixation cross)이 흰색 화면 중앙 에 나타나는 단계로, 다음 자극이 제시되기 전 대상자의 시선을 화 면 중앙으로 유도하여 시선이 특정 위치에 치우치지 않도록 하였 다. (2) 인지부하 과제는 숫자 외우기 과제 제시 단계(Digit recall task)로써 인지부하(고, 저)에 따라 두 개의 조건으로 구성하여 실 험을 진행하였다. 높은 인지부하 조건(high preload condition)에서 는 숫자 4 개를 제시하였고, 낮은 인지부하 조건(low preload condition)에서는 숫자 1 개를 제시하였다. 숫자는 화면에 1 초당 1 개씩 제 시되었다. (3) 그림 단서 제시 단계에서는 단어 재인 과제에서 제시 될 그림을 약 2 초간 미리 보여주어 어떤 단어가 나올지 파악하도록 하였다. (4) 준비 단계는 앞서, (1)번과 유사하게 ‘+’응시점(fixation cross)이 흰색 화면에 제시되어 시선을 중앙에 집중하도록 유도하 였다. (5) 단어 재인 단계는 각 목록 당, 메꿈질(Filer) 단어들로만 구 성된 연습 문항 4 개, 목표자극 문항 40 개와 메꿈질 자극 문항 40 개 로 이루어졌다. 총 84 개 문항으로 구성되며, 어휘는 중복되지 않는 다. 또한, 4 개의 흑백 그림과 함께 목표단어를 들려준 후, 정답은 버 튼 박스로 선택하여 응답하는 방식을 적용하였다. 이후, (6) 숫자 응 답 단계로 (2)단계에서 화면으로 제시된 숫자를 회상하여 답하도 록 하였다. 인지부하 조건인 숫자 외우기 과제는 방음 부스 밖에서 부스 내부에 설치된 스피커를 통해 듣고 연구자가 바로 전사하였 고, 즉시 전사가 어려운 경우에는 mp3 player를 통해 녹음하여 추 후 분석을 진행하였다.

본 실험은 순서 효과(order effect)를 배제하기 위하여 실험자극 의 순서 구성을 다르게 하는 교차균형화(count-balancing)를 실시 하였다. 전체 실험 구성은 인지부하 조건의 순서를 다르게 구성한 2 개 $(\mathrm{A}, \mathrm{B})$ 버전으로 진행하였다. 또한, 인지부하 조건에서 제시된 해 당 숫자는 1 에서 9 까지 숫자를 무작위로 선정 및 배열하였다. 동일 한 숫자가 연속적으로 나오지 않되, 실험 내에서 모든 숫자가 동일 한 횟수로 나오도록 구성하였다. 또한, 단어 재인 과제에서 목표단 어 그림이 같은 위치에서 2 회 이상 연속적으로 제시되지 않도록 하 였고, 각 자극 위치별 정답 빈도수를 동일하게 하였다. 해당 실험 제 시 순서 및 자극 예시는 Figures 1, 2,3과 같다.

\section{자료분석}

\section{정확도(Accuracy)}

본 실험의 반응정확도는 대상자가 인지부하 조건과제, 단어 재인 과제에서 모두 정반응한 경우만 고려하여 분석하였다. 정반응한 문항 수를 각 조건의 전체 문항 수인 20 으로 나눈 후, 100 을 곱하여 계산하였다.

반응정확도 $(\%)=($ 정반응한 문항 수/전체 문항 수 $) \times 100$

\section{반응시간(Response Time)}

본 실험의 반응시간은 반응정확도와 동일하게 대상자가 인지부 하 조건과제, 단어 재인 과제에서 모두 정반응한 경우만 고려하여 


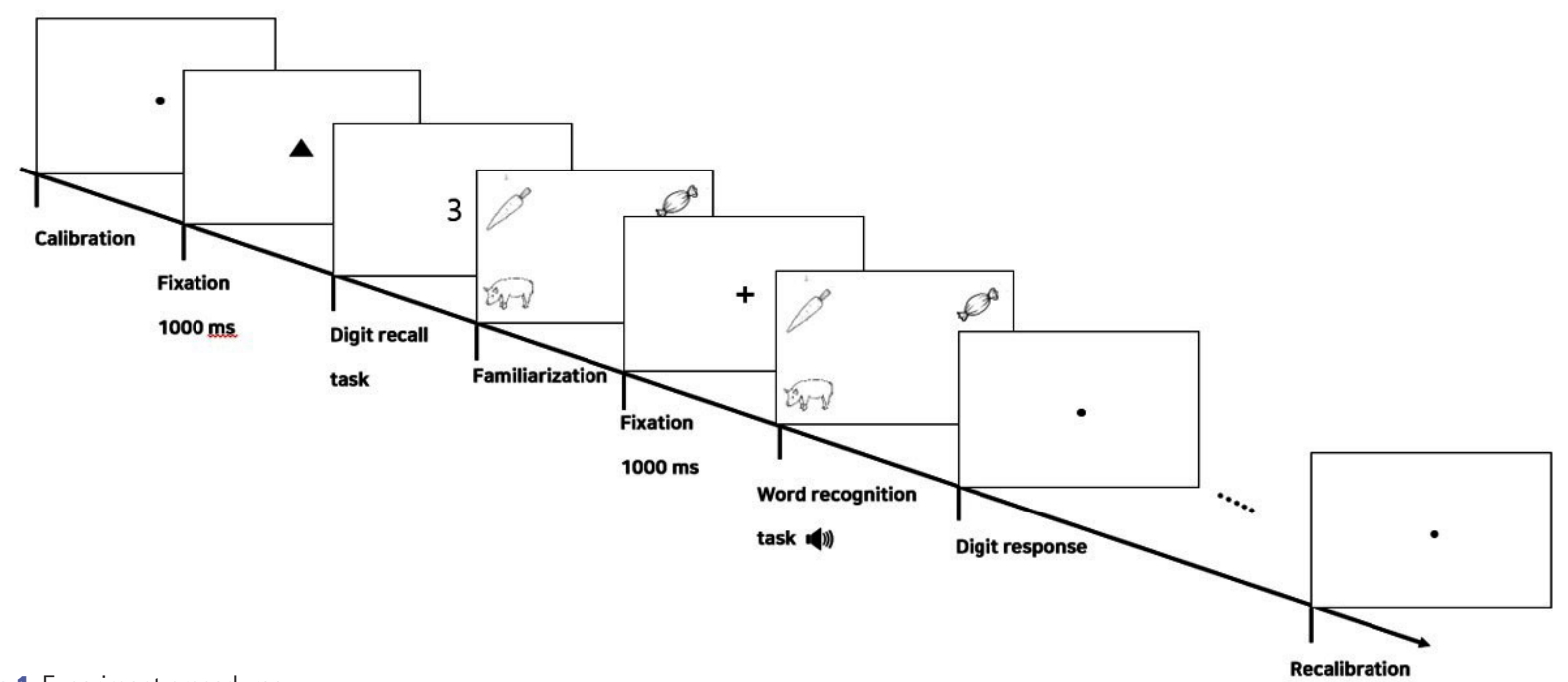

Figure 1. Experiment procedures.

4 Digits (high)

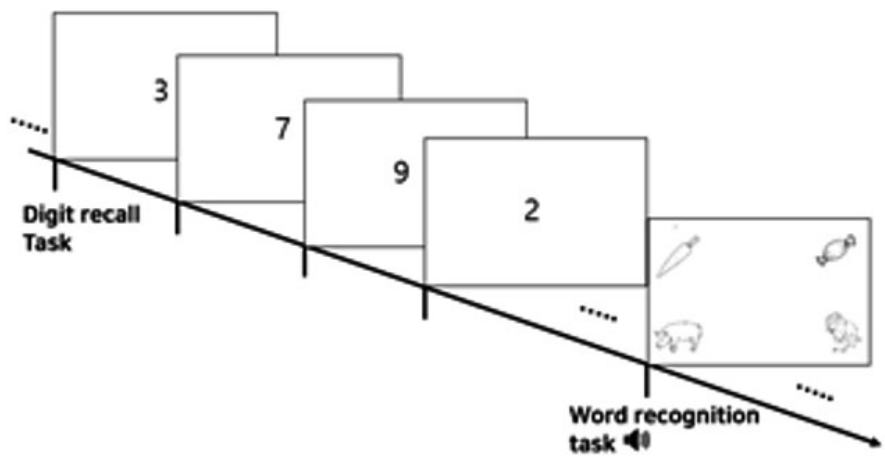

1 Digit (low)

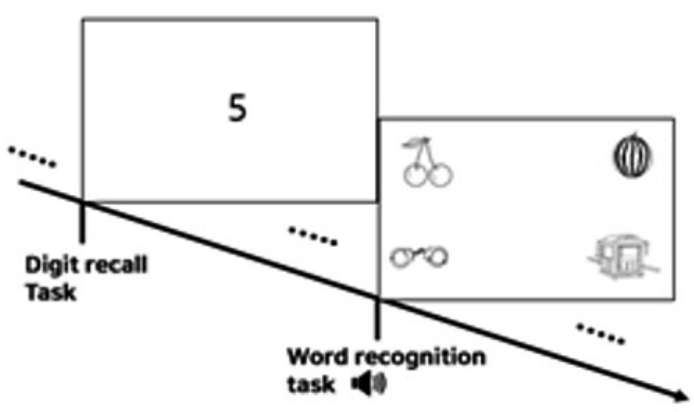

Figure 2. An example of experimental procedure for digit load condition.

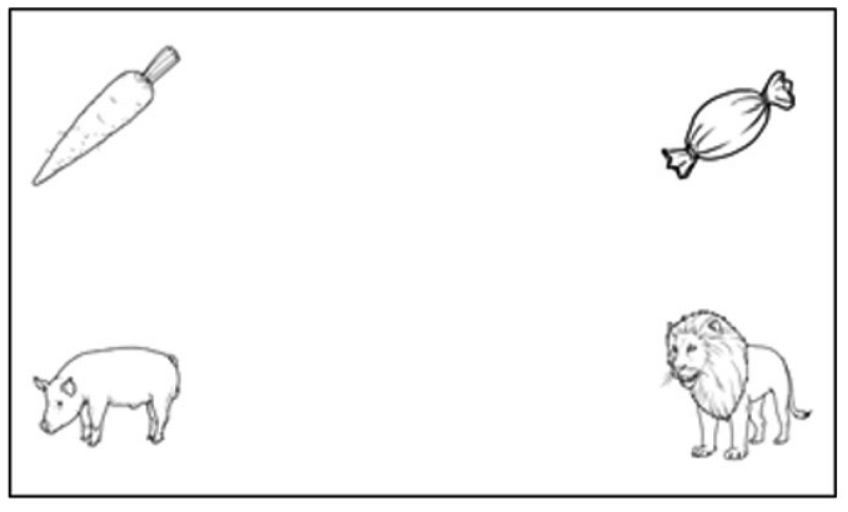

Figure 3. A sample display from experiment. The target object (target, lion/saja), phonologically related to one of the other objects (the phonological competitor, candy/sa-tang), semantically related to one of the other objects (the semantic competitor, pig/ dwae-ji), and unrelated to the target object (unrelated competitor, carrot/ dang-geun).
분석하였다. 반응시간은 단어 재인 과제에서 청각적 자극이 시작 하는 구간(onset)부터 대상자가 버튼을 눌러 답을 선택한 구간까지 의 시간으로 계산하였고, 반응시간은 밀리세컨드(msec) 단위로 측 정하였다.

\section{목표자극 시선고정비율(Proportion of Target Fixation)}

본 실험의 목표자극의 시선고정비율도 모두 정반응한 경우만 고 려하여 분석하였다. 목표자극의 시선고정비율은 화면에 제시된 4 개의 그림자극 중 다른 그림자극보다 목표자극 그림에 시선이 고정 된 횟수의 비율이다. 목표자극의 시선고정횟수를 목표자극과 3 개 의 방해자극의 시선고정횟수를 더한 값으로 나누어 계산하였다. 세부적으로 대상자의 시선고정비율은 Allopenna, Magnuson과 Tanenhaus (1998) 및 Ben-David 등(2011)의 연구를 참고하여 개별 
데이터를 $100 \mathrm{~ms}$ 단위로 시간 구간을 나누어 $200 \mathrm{~ms}$ 구간씩 시간 구간 분석을 진행하였다. 단어가 청각적으로 제시되는 구간(onset) 부터 단어가 끝나는 구간(offset)까지 총 $1,000 \mathrm{~ms}$ 의 구간의 시선고 정비율을 분석하였다. 단, 단어 시작 후, $200 \mathrm{~ms}$ 은 분석에서 제외하 여 대상 단어가 시작된 후, $1,200 \mathrm{~ms}$ 까지의 구간을 분석하였다. 단 어 시작 후, $200 \mathrm{~ms}$ 구간은 음성 정보에 대한 처리를 위해 대뇌를 거 쳐 행동하기까지의 최저 반응시간을 반영한 것으로 분석에서 제외 하였다(Allopenna et al., 1998).

목표자극 시선고정비율 $=$ 목표자극 시선고정 횟수/총 시선 고정

$$
\text { 횟수(목표자극+방해자극) }
$$

\section{자료분석}

본 연구의 종속변수인 반응정확도, 반응시간, 목표자극 시선고 정비율은 대상자에게서 얻은 시선추적 데이터를 SR Research사의 Eye Link Data Viewer 3.2.1 [Computer software] (2018)과 Microsoft Excel 2016 프로그램을 이용하여 분석하였다.

추출 과정에서 선행연구(Amso, Johnson, \& Markant, 2014)에 따라 시선 보정 및 검증을 실시하였을 때, 동공의 $\mathrm{X}$ 축, $\mathrm{Y}$ 축의 편차 (Eye Deviaton)가 불안정한 값은 분석에서 제외하였다. 또한, 표준 편차(SD)를 구하여 $\pm 3 \mathrm{SD}$ 범위를 벗어나는 값은 이상값(outlier) 으로 처리하여 분석에서 제외하였고, 분석 구간에서 반응이 기록 되지 않은 문항도 시선추적 자료분석에서 제외하였다.

\section{자료의 통계적 처리}

자료의 통계적 처리는 SPSS (SPSS Inc., Chicago, IL, USA)를 사 용하였다. 단어 재인 과제에서 청년과 노년 집단 간 반응정확도 및 반응시간에 유의한 차이가 있는지 알아보기 위해 삼원혼합분산분 석(3-way mixed ANOVA)을 실시하였다. 또한, 목표자극 시선고정 비율이 단어 재인 과제에서 시간 구간에 따른 인지부하 조건과제

Table 2. Descriptive statistics of accuracy on word recognition task as a working memory capacity and cognitive load condition for each group

\begin{tabular}{lccc}
\hline Group & WM & DL (high) & DL (low) \\
\hline Young (N=24) & High ( $=12)$ & $94.58(7.53)$ & $96.67(4.44)$ \\
& Low ( $=12)$ & $95.83(7.02)$ & $97.08(4.50)$ \\
Old (N=24) & Mean & $95.21(7.14)$ & $96.88(4.38)$ \\
& High ( $=12)$ & $95.00(4.26)$ & $92.92(9.16)$ \\
& Low ( $=12)$ & $85.83(11.65)$ & $91.67(8.62)$ \\
& Mean & $90.42(9.77)$ & $92.29(8.72)$ \\
\hline
\end{tabular}

Values are presented as mean (SD).

WM = Working Memory capacity; DL = Digit Load condition.
(고, 저) 및 작업기억용량(고, 저)에 따라 청년 및 노년 집단 간 유의 한 차이가 있는지 알아보기 위해 사원혼합분산분석(4-way mixed ANOVA)을 실시하였다. 정규분포 및 구형성 가정 검증을 실시하 여 모수통계 사용 가설 검증이 충족됨을 확인하였다. 그러나 구형 성 가정이 충족되지 않았을 경우에는 Greenhouse-Geiser의 $F$ 및 $p$-value를 보고하였다.

\section{연구결과}

\section{반응정확도}

반응정확도 차이가 통계적으로 유의한지 알아보기 위해 집단 X 인지부하 조건 X 작업기억용량 삼원혼합분산분석(3-way mixed ANOVA)을 실시하였다. 단어 재인 과제에서 청년과 노년 집단의 반응정확도 기술통계 및 분산분석 결과는 Tables 2,3 과 같다. 분석 결과, 두 집단간주효과가통계적으로 유의하였다 $\left(F_{(1,44)}=7.830, p<.01\right)$. 즉, 노년 집단(평균 $91.35 \%$ )은 청년 집단(평균 $96.04 \%$ )에 비해 유의 하게 낮은 반응정확도를 보였으며, 반응정확도 그래프는 Figure 4 와같다.

\section{반응시간}

반응시간 차이가 통계적으로 유의한지 알아보기 위해 집단 X 인 지부하 조건 X 작업기억용량 삼원혼합분산분석(3-way mixed ANOVA)을 실시하였다. 기술통계 및 분석결과는 Tables 4,5 에 제 시하며, 반응시간 그래프는 Figure 5 와 같다. 분석 결과, 먼저 청년 과 노년 집단 간 주효과가 통계적으로 유의하였다 $\left(F_{(1,44)}=16.483\right.$,

Table 3. ANOVA results from the accuracy on word recognition task as a working memory capacity and cognitive load condition for each group

\begin{tabular}{|c|c|c|c|c|c|}
\hline Distributed source & $\begin{array}{l}\text { Sum of } \\
\text { square }\end{array}$ & $\begin{array}{l}\text { Degree of } \\
\text { freedom }\end{array}$ & $\begin{array}{l}\text { Mean } \\
\text { square }\end{array}$ & $F$ & $p$ \\
\hline \multicolumn{6}{|l|}{ Between factor } \\
\hline G & 527.344 & 1 & 527.344 & 7.830 & $.008^{* *}$ \\
\hline WM & 114.844 & 1 & 114.844 & 1.705 & .198 \\
\hline$G \times W M$ & 219.010 & 1 & 219.010 & 3.252 & .078 \\
\hline Error & 2963.542 & 44 & 67.353 & & \\
\hline \multicolumn{6}{|l|}{ Within factor } \\
\hline $\mathrm{DL}$ & 75.260 & 1 & 75.260 & 1.598 & .213 \\
\hline $\mathrm{DL} \times \mathrm{G}$ & .260 & 1 & .260 & 0.006 & .941 \\
\hline $\mathrm{DL} \times \mathrm{WM}$ & 75.260 & 1 & 75.260 & 1.598 & .213 \\
\hline $\mathrm{DL} \times \mathrm{G} \times \mathrm{WM}$ & 114.844 & 1 & 114.844 & 2.439 & .126 \\
\hline Error & $2,071.875$ & 44 & 47.088 & & \\
\hline
\end{tabular}

$\mathrm{G}=$ Group; $\mathrm{WM}=$ Working Memory capacity; $\mathrm{DL}=$ Digit Load condition. ${ }^{* *} p<.01$. 


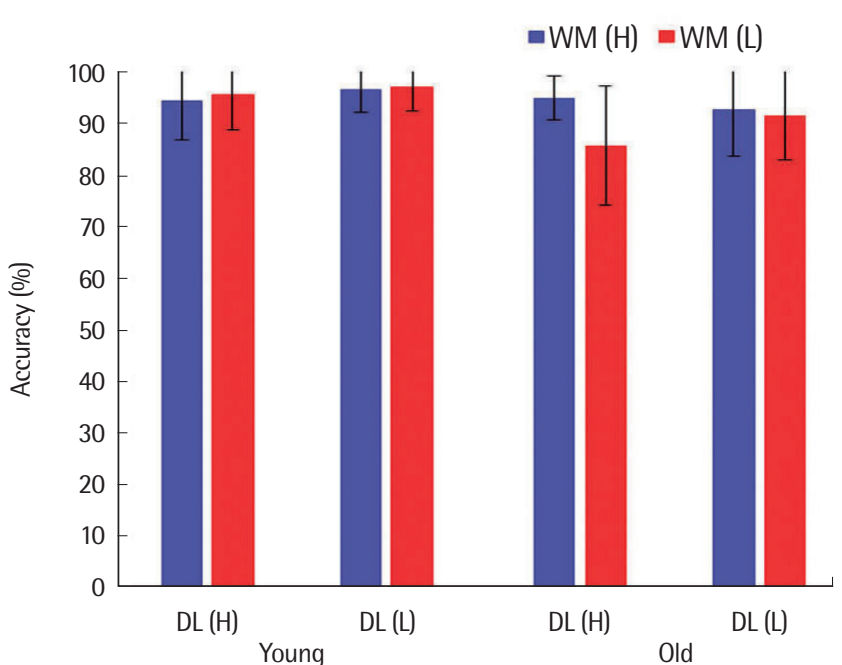

Figure 4. Accuracy on word recognition task for each group and condition. WM=Working memory capacity; $\mathrm{H}=$ High; $\mathrm{L}=\mathrm{Low} ; \mathrm{DL}=$ Digit load condition.

Table 4. Descriptive statistics of response time on word recognition task as a working memory capacity and cognitive load condition for each group

\begin{tabular}{lccc}
\hline Group & WM & DL (high) & DL (low) \\
\hline Young (N=24) & High (N=12) & $1,688.32(314.89)$ & $1,596.56(332.25)$ \\
& Low $(\mathrm{N}=12)$ & $1,539.94(206.87)$ & $1,609.53(277.41)$ \\
Old (N=24) & Mean & $1,614.13(271.35)$ & $1,603.04(299.41)$ \\
& High (N=12) & $1,963.27(442.04)$ & $1,899.32(355.73)$ \\
& Low (N=12) & $2,003.03(284.48)$ & $2,183.37(627.72)$ \\
& Mean & $1,983.15(364.10)$ & $2,041.34(519.64)$ \\
\hline
\end{tabular}

WM= Working Memory capacity; DL = Digit Load condition.

Table 5. ANOVA results from the response time on word recognition task as a working memory capacity and cognitive load condition for each group

\begin{tabular}{lrrrrr}
\hline $\begin{array}{l}\text { Distributed } \\
\text { source }\end{array}$ & Sum of square & $\begin{array}{c}\text { Degree of } \\
\text { freedom }\end{array}$ & Mean square & $F$ & $p$ \\
\hline Between factor & & & & & \\
$\quad$ G & $3,910,595.109$ & 1 & $3,910,595.109$ & 16.483 & $.000^{* *}$ \\
WM & $53,237.978$ & 1 & $53,237.978$ & .224 & .638 \\
GxWM & $316,313.491$ & 1 & $316,313.491$ & 1.333 & .254 \\
Error & $10,439,132.338$ & 44 & $237,253.008$ & & \\
Within factor & & & & & \\
DL & $13,313.522$ & 1 & $13,313.522$ & .301 & .586 \\
DL x & $28,795.262$ & 1 & $28,795.262$ & .650 & .424 \\
DL x WM & $246,816.323$ & 1 & $246,816.323$ & 5.571 & $.023^{*}$ \\
DL x x WM & $10,319.892$ & 1 & $10,319.892$ & .233 & .632 \\
Error & $1,949,276.641$ & 44 & $44,301.742$ & & \\
\hline
\end{tabular}

$\mathrm{G}=$ Group; $\mathrm{WM}=$ Working Memory capacity; $\mathrm{DL}=$ Digit Load condition. ${ }^{*} p<.05,{ }^{* *} p<.01$.

$p<.01)$. 즉, 노년 집단의 평균 반응시간은 $2,012.25(\mathrm{~ms})$, 청년 집단 의 평균 반응시간은 $1,608.59(\mathrm{~ms})$ 로 노년 집단은 청년에 비해 단어

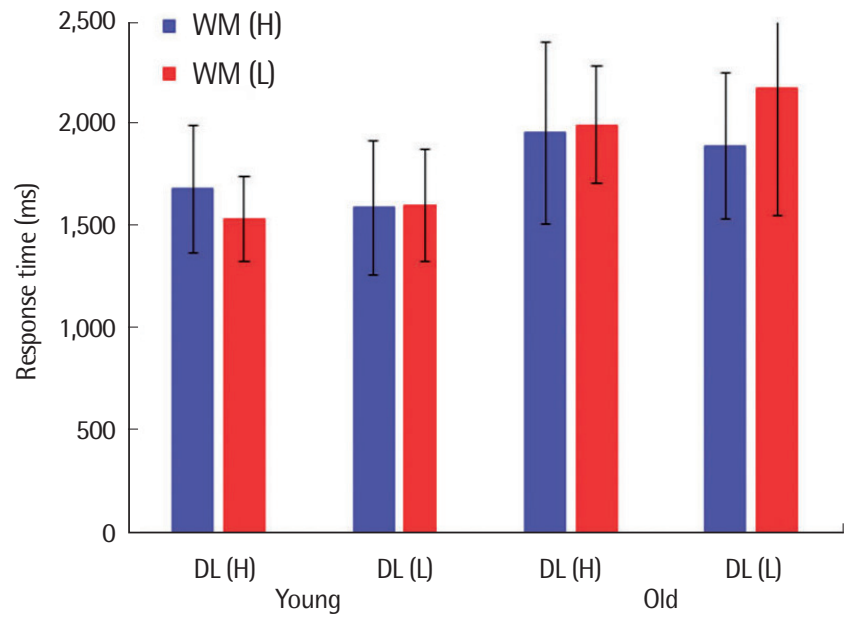

Figure 5. Response time on word recognition task for each group and condition.

WM= Working memory capacity; $\mathrm{H}=$ High; $\mathrm{L}=\mathrm{Low}$; $\mathrm{DL}=$ Digit load condition.

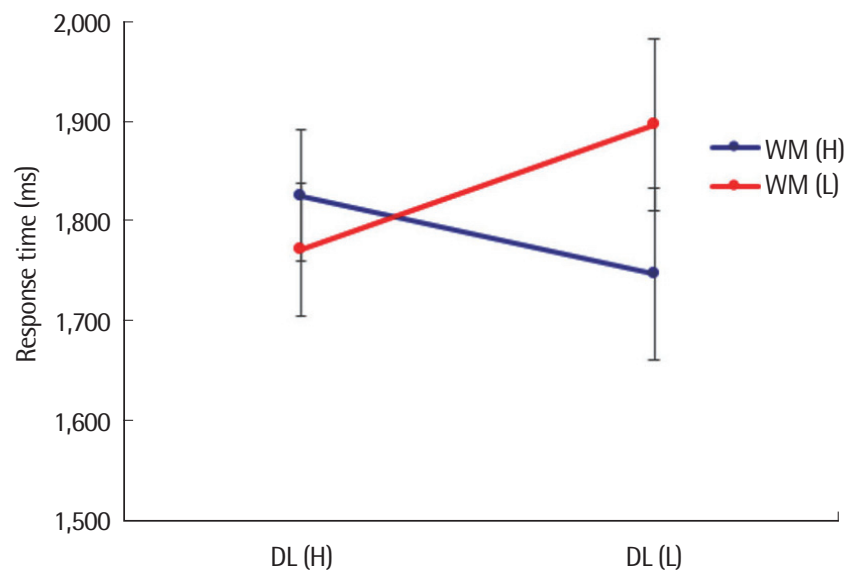

Figure 6. Response time on word recognition task for WM and DL condition. WM=Working memory capacity; $\mathrm{H}=$ High; $\mathrm{L}=\mathrm{Low}$; $\mathrm{DL}=$ Digit load condition.

선택 하는데, 시간이 더 걸리는 것으로 나타났다. 다음으로 인지부 하 조건(고, 저) 및 작업기억용량(고, 저) 간 상호작용이 통계적으로 유의하였다 $\left(F_{(1,44)}=5.571, p<.05\right)$. 작업기억용량이 높은 집단과 낮 은 집단에 따라 차이 패턴이 다르게 나타났다. 구체적으로 작업기 억용량 높은 집단의 경우, 높은 인지부하 조건에서 반응시간이 증 가하였다. 반면, 작업기억용량이 낮은 집단의 경우, 낮은 인지부하 조건에서 반응시간이 증가하였다. 인지부하 조건(고, 저)에 따른 작 업기억용량(고, 저)에 대한 반응시간 그래프는 Figure 6과 같다.

\section{목표자극 시선고정비율}

목표자극의 시선고정비율 차이가 통계적으로 유의한지 알아보 기 위해 집단 $\times$ 인지부하 조건 $\times$ 작업기억용량 $\times$ 시간 구간 사원혼 
합분산분석(4-way mixed ANOVA)을 실시하였다. 청각적으로 제 시되는 단어가 시작하고 끝나는 구간을 5 개의 구간으로 나누어 분 석하였다. 구체적으로 구간1 (200-400 ms), 구간2 (400-600 ms), 구 간3 (600-800 ms), 구간4 (800-1,000 ms), 구간5 (1,000-1,200 ms)로 나누어 분석하였으며, 기술통계 및 분석결과는 Tables 6, 7에 제시 하였으며, 시선고정비율 그래프는 Figure 7과 같다.

분석 결과, 먼저 청년과 노년 집단 간 주효과가 통계적으로 유의 하였다 $\left(F_{(1,44)}=6.794, p<.05\right)$. 즉, 노년 집단의 평균 목표자극 시선 고정비율은 .323 , 청년 집단의 목표자극 시선고정비율은 .365 로 노 년 집단은 청년 집단에 비해 목표자극 시선고정비율이 낮았다. 다 음으로 시간 구간에 따른 집단 간 이차 상호작용이 통계적으로 유 의하였다 $\left(F_{(4,176)}=7.777, p<.001\right)$. 유의한 이차상호작용에 대한 사 후검정으로 집단별로 시간 구간에 따른 차이를 살펴보기 위해 독 립표본 $t$ 검정(independent samples $t$-test)을 실시한 결과, 집단에 따라 구간4 (800-1,000 ms), 구간5 (1,000-1,200 ms)에서 유의한 차 이를 보였다. 구체적으로 노년 집단은 낮은 인지부하 조건의 구간 4 와 구간5에서 청년 집단보다 통계적으로 유의하게 시선고정비율 이 낮았다 $\left.\left(t_{(46)}=-3.307, p<.01\right), t_{(46)}=-2.925, p<.01\right)$. 높은 인지부 하 조건의 구간5에서도 유의하게 청년보다 목표자극을 오랫동안 응시하지 않았다 $\left(t_{(46)}=-4.356, p<.01\right)$. 시간 구간에 따른 집단 간 시선고정비율은 Figure 8 과 같다. 다음으로 시간 구간에 따른 인지 부하 조건(고, 저) 간 이차 상호작용이 통계적으로 유의하였다 $\left(F_{(4,176)}=3.424, p<.05\right)$. 유의한 이차상호작용에 대한 사후검정으 로 시간 구간별로 인지부하 조건 간 차이를 살펴보기 위해 대응표 본 $t$ 검정(paired $t$-test)을 실시하였다. 결과적으로 구간1 (200-400 $\mathrm{ms})$, 구간5 (1,000-1,200 ms)에서 인지부하 조건에 따라 유의한 차

Table 6. Descriptive statistics of proportion of fixation over time to the target on word recognition task for each group and condition. task for each group and condition

\begin{tabular}{|c|c|c|c|c|c|}
\hline \multirow{2}{*}{$\mathrm{DL}$} & \multirow{2}{*}{$\begin{array}{c}\text { Old } \\
(N=24)\end{array}$} & \multicolumn{2}{|c|}{ Young ( $\mathrm{N}=24)$} & \multicolumn{2}{|c|}{ Old ( $N=24)$} \\
\hline & & WM (high) & WM (low) & WM (high) & WM (low) \\
\hline \multirow[t]{5}{*}{ High } & Phase 1 & $.26(.08)$ & $.20(.09)$ & $.20(.09)$ & $.28(.10)$ \\
\hline & Phase 2 & $.24(.09)$ & $.19(.08)$ & $.24(.10)$ & $.28(.13)$ \\
\hline & Phase 3 & $.27(.09)$ & $.32(.11)$ & $.29(.13)$ & $.30(.07)$ \\
\hline & Phase 4 & $.45(.11)$ & $.47(.18)$ & $.42(.08)$ & $.42(.11)$ \\
\hline & Phase 5 & $.62(.13)$ & $.62(.17)$ & $.45(.12)$ & $.43(.15)$ \\
\hline \multirow[t]{5}{*}{ Low } & Phase 1 & $.22(.07)$ & $.18(.07)$ & $.20(.09)$ & $.21(.11)$ \\
\hline & Phase 2 & $.24(.09)$ & $.19(.12)$ & $.17(.08)$ & $.23(.08)$ \\
\hline & Phase 3 & $.31(.15)$ & $.27(.14)$ & $.25(.11)$ & $.28(.12)$ \\
\hline & Phase 4 & $.52(.14)$ & $.46(.12)$ & $.39(.07)$ & $.39(.09)$ \\
\hline & Phase 5 & $.67(.14)$ & $.60(.09)$ & $.52(.09)$ & $.52(.19)$ \\
\hline
\end{tabular}

WM=Working Memory capacity; DL = Digit Load condition.
이가 나타났다. 구체적으로 구간1에서는 높은 인지부하 조건에서 시선고정비율이 높았고, 구간5에서는 낮은 인지부하 조건에서 시 선고정비율이 높았다 $\left.\left(t_{(47)}=-2.125, p<.05\right), t_{(47)}=2.289, p<.05\right)$. 시 간 구간에 따른 인지부하 조건 간 시선고정비율은 Figure 9와 같다.

추가로 시간 구간에 따라 인지부하 조건(고, 저) 및 집단 간 삼차 상호작용이 통계적으로 유의하였다 $\left(F_{(4,176)}=2.465, p<.05\right)$. 유의한 삼차상호작용에 대한 사후검정으로 시간 구간에 따른 인지부하 조건(고, 저)에 대해 집단별로 이원반복측정분산분석(2-way repeated ANOVA)을 실시하였다. 그 결과, 청년 집단에서는 유의한 차이가 나타나지 않았지만, 노년 집단에서는 시간 구간과 인지부하 조건(고, 저) 간 이차상호작용이 유의하였다 $\left(F_{(4,92)}=5.070, p<.01\right)$. 구체적으로 대응표본 $t$ 검정(paired $t$-test)을 통해 시간 구간에 따 른 차이를 확인하였고, 구간2 (400-600 ms), 구간5 (1,000-1,200 ms) 에서 유의미한 차이가 나타났다 $\left(t_{(23)}=-2.323, p<.05\right), t_{(23)}=2.931$, $p<.01)$. 즉, 노년 집단은 구간 2 의 높은 인지부하 조건에서 시선고정 비율이 높았고, 구간5의 낮은 인지부하 조건에서 시선고정비율이 높게 나타났으며, 시간 구간에 따라 인지부하 조건(고, 저) 및 집단

Table 7. ANOVA results from the proportion of fixation over time to the target on word recognition task for each group and condition

\begin{tabular}{|c|c|c|c|c|c|}
\hline $\begin{array}{l}\text { Distributed } \\
\text { source }\end{array}$ & $\begin{array}{l}\text { Sum of } \\
\text { Square }\end{array}$ & $\begin{array}{l}\text { Degree of } \\
\text { freedom }\end{array}$ & $\begin{array}{l}\text { Mean } \\
\text { square }\end{array}$ & $F$ & $p$ \\
\hline \multicolumn{6}{|l|}{ Between factor } \\
\hline G & .214 & 1 & .214 & 6.794 & $.012^{*}$ \\
\hline WM & .002 & 1 & .002 & .064 & .802 \\
\hline $\mathrm{G} \times \mathrm{WM}$ & .082 & 1 & .082 & 2.601 & .114 \\
\hline Error & 1.385 & 44 & .031 & & \\
\hline \multicolumn{6}{|l|}{ Within factor } \\
\hline $\mathrm{DL}$ & .003 & 1 & .003 & .212 & .647 \\
\hline $\mathrm{DL} \times \mathrm{G}$ & .011 & 1 & .011 & .772 & .384 \\
\hline $\mathrm{DL} \times \mathrm{WM}$ & .016 & 1 & .016 & 1.140 & .292 \\
\hline $\mathrm{DL} \times \mathrm{WM} \times \mathrm{G}$ & .014 & 1 & .014 & .972 & .330 \\
\hline Error (L) & .632 & 44 & .014 & & \\
\hline $\mathrm{T}$ & 8.333 & 4 & 2.083 & 151.547 & 6.0381 \\
\hline$T \times G$ & .428 & 2.527 & .169 & 7.777 & $.000^{* *}$ \\
\hline T×WM & .014 & 4 & .004 & .263 & .901 \\
\hline $\mathrm{T} \times \mathrm{G} \times \mathrm{WM}$ & .053 & 4 & .013 & .956 & .433 \\
\hline Error $(\mathrm{T})$ & 2.419 & 176 & .014 & & \\
\hline $\mathrm{DL} \times \mathrm{T}$ & .097 & 4 & .024 & 3.424 & $.010^{*}$ \\
\hline $\mathrm{DL} \times \mathrm{T} \times \mathrm{G}$ & .070 & 4 & .017 & 2.465 & $.047^{*}$ \\
\hline $\mathrm{DL} \times \mathrm{T} \times \mathrm{WM}$ & .011 & 4 & .003 & .397 & .811 \\
\hline $\mathrm{DL} \times \mathrm{T} \times \mathrm{G} \times \mathrm{WM}$ & .036 & 4 & .009 & 1.281 & .279 \\
\hline Error $(L \times T)$ & 1.248 & 176 & .007 & & \\
\hline
\end{tabular}

$\mathrm{G}=$ Group; $\mathrm{WM}=$ Working Memory capacity; $\mathrm{DL}=$ Digit Load condition; $\mathrm{T}=$ Time course.

${ }^{*} p<.05,{ }^{* *} p<.01$. 

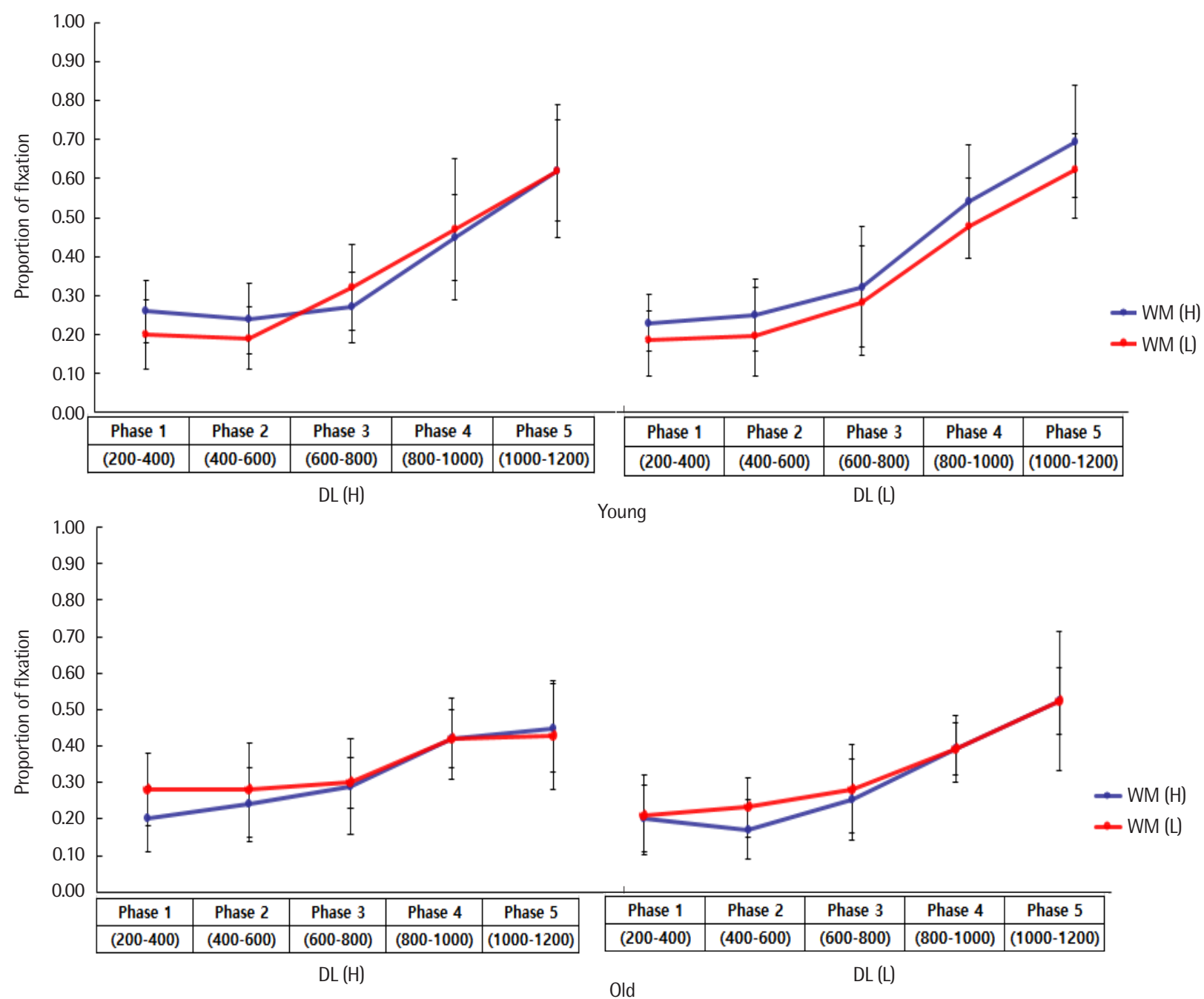

Figure 7. Proportion of fixation on word recognition task for each group and condition.

WM=Working memory capacity; $\mathrm{H}=\mathrm{H}$ igh; $\mathrm{L}=\mathrm{Low} ; \mathrm{DL}=$ Digit load condition.

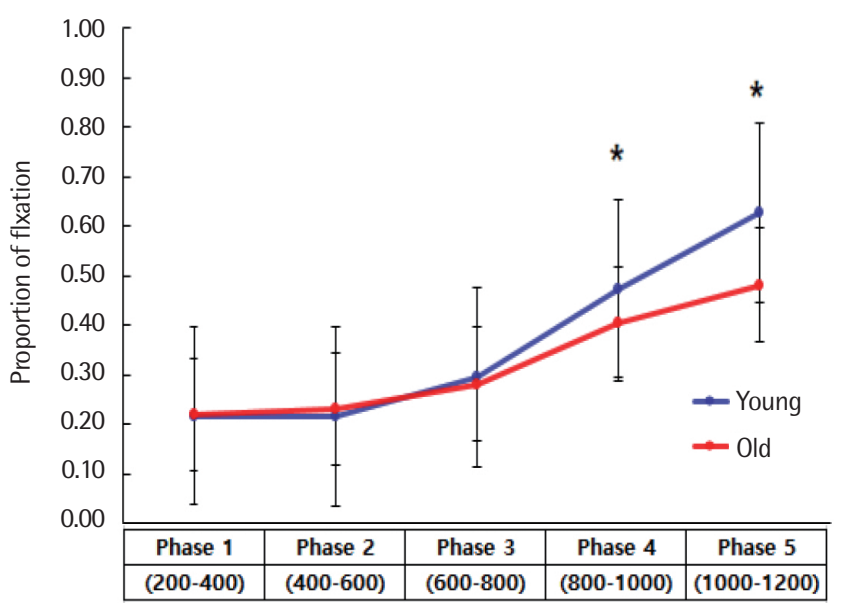

Figure 8. Proportion of fixation over time to the target for each group.

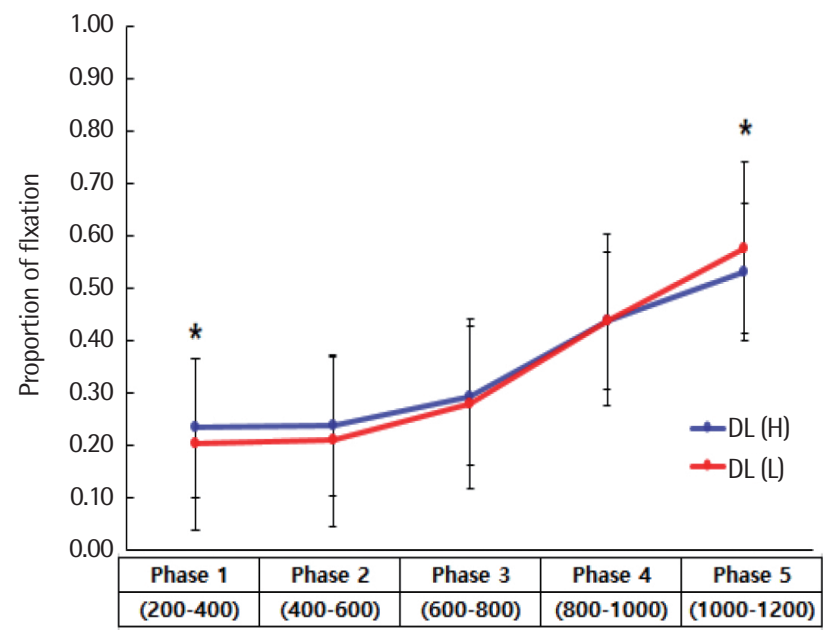

Figure 9. Proportion of fixation over time to the target for digit load condition. $\mathrm{DL}=$ Digit load condition; $\mathrm{H}=$ High; $\mathrm{L}=\mathrm{L}$ ow. 


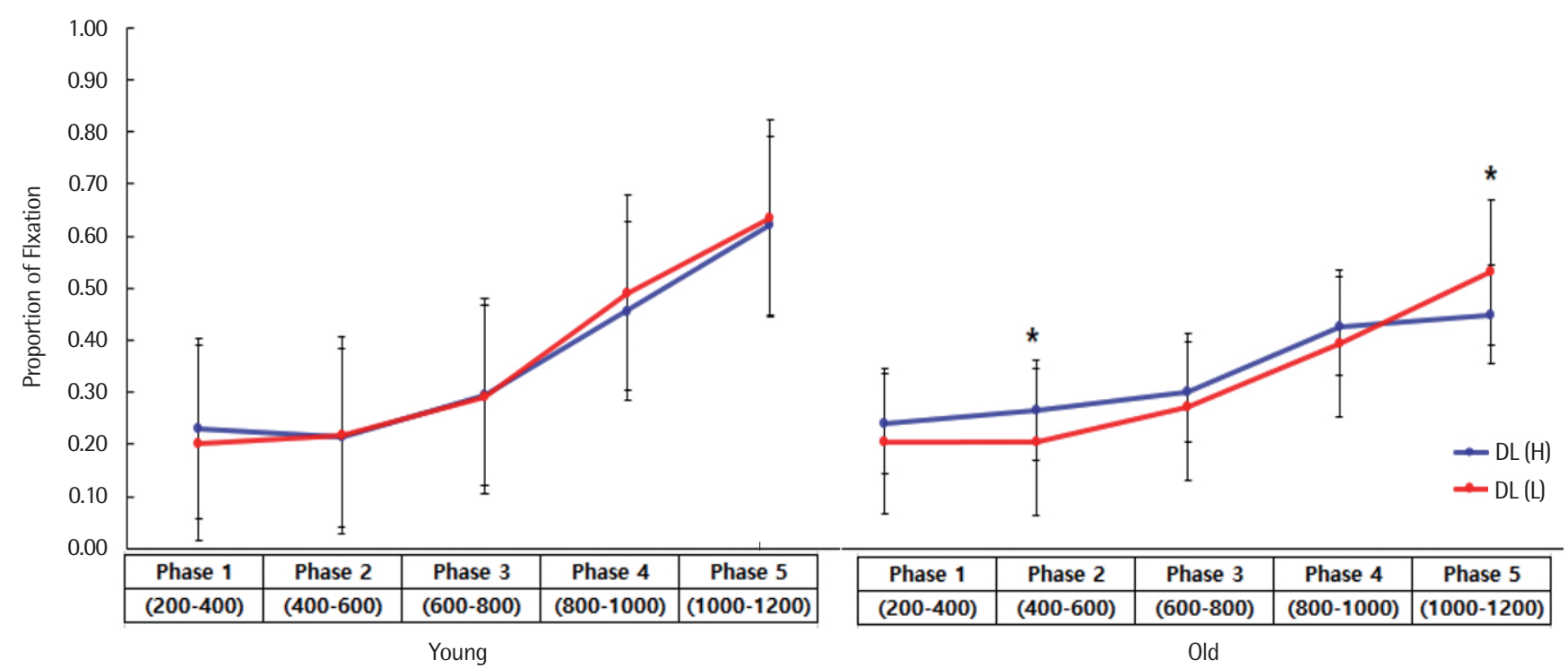

Figure 10. Proportion of fixation over time to the target for each group and digit load condition. $\mathrm{DL}=$ Digit load condition; $\mathrm{H}=$ High; $\mathrm{L}=\mathrm{Low}$.

간 시선고정비율 그래프는 Figure 10과 같다.

\section{논의 및 결론}

본 연구는 청년과 노년 집단을 대상으로 인지부하 조건에 따른 작업기억용량의 차이가 단어 재인에 미치는 영향을 확인하고자 하 였다. 따라서 단어 재인 과제에서의 시선을 추적한 후, 인지부하 조 건(고, 저) 및 작업기억용량(고, 저)에 따라 청년 및 노년 집단 간 (1) 반응정확도, (2) 반응시간, (3) 목표자극 시선고정비율을 알아보았 다. 본 연구의 결과에 대해 오프라인 측정변수인 반응정확도, 반응 시간과 온라인 측정변수인 시선고정비율로 나누어 살펴보면 아래 와같다.

\section{반응정확도와 반응시간}

오프라인 측정변수인 반응정확도 및 반응시간의 경우, 단어 재 인 과제에서 청년 및 노년 집단에서만 차이가 유의하였다. 오프라 인 측정 결과는 다음과 같이 해석할 수 있다. 청년 집단보다 노년 집 단에서 인지부하 과제와 단어 재인 과제에서 모두 낮은 수행과 느 린 반응시간을 보였다. 이는 노화로 인해 언어처리능력이 감소된다 고 보고한 연구 결과들과 일치한다(Feyereisen, 1997; Kim, Choi, \& Hwang, 2016; Nicholas, Barth, Obler, Au, \& Albert, 1997; Ramsay, Nicholas, Au, Olber, \& Albert, 1999; Schmitter-Edgecombe, Vesneski, \& Jones, 2000; Yeon, et al., 2017).

반응정확도는 집단 간 차이를 제외하고 작업기억용량 또는 인지
부하에 따른 주효과, 상호작용 효과는 나타나지 않았다. 반응정확 도 결과와 달리, 작업기억용량에 따른 인지부하 조건 간 반응시간 의 차이가 유의하였다. 작업기억용량이 높은 집단의 경우, 높은 인 지부하 조건에서 반응시간이 증가하였다. 이러한 결과는 앞서 서론 에서 언급한 Just와 Carpenter (1992)의 제한된 용량 자원으로 설명 이 가능하며, 인지적 기억부하가 증가될 때, 수행력 감소가 나타난 다고 보았다. 즉, 선행연구에 따라 작업기억용량이 높은 집단의 경 우, 높은 인지부하 조건에서 제시된 정보를 저장하고 처리하는데 이미 많은 자원을 사용했기 때문에 단어 재인 과제에서 반응시간 이 오래 걸린 것으로 해석해볼 수 있다. 반면, 작업기억용량이 낮은 집단의 경우, 낮은 인지부하 조건에서 반응시간이 증가하였다. 상 대적으로 낮은 인지부하 조건에서는 숫자 외우기 과제에서 단어 재 인 과제로 빠른 주의전환이 필요하다. 이에 낮은 작업기억용량 집 단은 빠른 주의전환이 이루어지지 않아 반응시간이 증가한 것으로 해석해볼 수 있다. 경도인지장애(mild cognitive impairment, MCI) 와 정상 노년 집단을 대상으로 언어적 작업기억 과제 유형 및 처리 부담 조건이 작업기억 과제 수행에 미치는 영향에 대한 연구(Tak, Sung, Jeong, \& Kim, 2016) 결과에 의하면, 정상 노년층보다 MCI가 언어적 작업기억 과제에서 정확도가 낮았으며, 반응시간이 증가하 는 경향을 보였다. 특히, 시간적 처리부담에서는 작업기억 과제 유 형에 따라 정상 노년층과 $\mathrm{MCI}$ 의 차이가 나타났으며, 이에 따라 시 간적 처리부담이 인지적 기억부하를 증가시키고 $\mathrm{MCI}$ 의 처리과정 에 영향을 미쳐 언어적 작업기억 과제의 반응시간 증가에 기여했음 을 밝혔다. 
선행연구를 참고하여 주의전환과 할당을 반복하는 과정에서 시 간적 요인이 작업기억용량에 큰 영향을 미친다고 볼 수 있다. 즉, 시 간 경과에 따라 목표자극에 주의를 집중하거나, 방해자극에 주의 를 억제하는 것이 상대적으로 높은 수준의 인지적 자원을 요구하 는 과정이며, 이로 인해 작업기억에 인지적 부하가 과중된 것으로 설명할 수 있다(Portrat, Barrouillet, \& Camos, 2008). 따라서 본 연 구결과에서 인지부하 과제를 시간적인 관점에서 보았을 때, 낮은 인지부하의 경우, 높은 인지부하보다 이전 과제를 억제하고 새로운 과제로 빠르게 주의전환 하는 과정에 어려움을 느낀 것으로 해석 해볼수 있다.

본 연구의 오프라인 측정결과에서 반응정확도는 작업기억용량 및 인지부하에 따른 차이를 보여주지는 못했으나, 반응시간은 작업 기억용량 및 인지부하에 따른 차이를 보여주기도 하였다. 이에 대 해 기능성자기공명영상(functional magnetic resonance imaging, $\mathrm{fMRI}$ )을 활용하여 작업기억 과제 수행력을 확인한 연구(Honey, Bullmore, \& Sharma, 2000)에 의하면 뇌의 기능적인 부분과 상관 관계를 보이는 것은 정확도가 아니라 반응시간이라고 밝혔으며, 이 는 반응시간이 과제의 수행력을 더 영향력 있게 예측할 수 있는 요 소임을 보여주었다. 이를 통해 반응정확도 변수만으로는 작업기억, 인지부하에 따른 영향을 살펴보는데 한계가 있다고 해석할 수 있 다. 따라서 반응시간 변수나 온라인 측정변수를 통한 추가 분석이 필요함을 보여주었다.

\section{시선고정비율}

온라인 측정변수인 시선고정비율의 경우, 단어 재인 과제에서 청 년과 비교하면 노년 집단의 시선고정비율이 낮았다. 더욱이 시간 구간에 따라 집단 간 차이가 있었으며, 구간 4 와 구간5에서 노년 집 단이 청년 집단보다 시선고정비율이 낮았다. Ehrlich와 Rayner (1981)는 맥락 내에서 예측 가능한 단어가 상대적으로 고정 시간 (fixation duration)이 짧고 고정 개수가 적다는 결과를 보여주었다. 이에 대해 노인은 시력 이외에도 감각 및 운동 기능이 전반적으로 저하되어 청년보다 읽기 시간이 상대적으로 느리며(Choi, Lowder, Ferreira, Swaab, \& Henderson, 2017; Kliegl, Grabner, Rolfs, \& Engbert, 2004; Rayner, Reichle, Stroud, Williams, \& Pollatsek, 2006; Stine-Morrow, Noh, \& Shake, 2010), 이로 인해 노인이 청년 보다 맥락에 의존하며, 단어를 예측하는 경향이 더 크게 나타난다 고 보았다(Cohen \& Faulkner, 1983; Madden, 1988; Speranza, Daneman, \& Schneider, 2000; Stine-Morrow, Miller, Gagne, \& Hertzog, 2008; Stine-Morrow, Miller, \& Nevin, 1999). Cohen과 Faulkner (1983)의 연구는 어휘 판단 과제(lexical decision task)를
통해 맥락 의존도가 연령 집단별로 차이가 있음을 보여주었다. 구 체적으로 목표단어는 문장의 맨 끝에 위치하도록 하였으며, 먼저 화면에 선행 맥락을 제시한 뒤, 목표단어를 제시하는 방식으로 어 휘 판단 과제를 실시하였다. 연구결과, 청년에 비해 노인은 단어 예 측도에 따른 반응시간 비율의 차이가 컸으며, 이를 통해 노인이 청 년보다 맥락에 더 의존하는 경향이 있음을 보여주었다. 또한, Rayner 등(2006)은 읽기 과정에서 노인이 청년보다 건너뛰기(skip) 비율이 훨씬 높고 도약(saccade) 거리가 길었음을 보고하였다. 즉, 노인들은 저하된 단어 재인 능력을 보완하기 위해 청년보다 글을 훝어 읽는 경향이 더 크며, 이러한 경향이 높은 건너뛰기 비율과 긴 도약 거리로 나타난다는 것이다. 이러한 선행연구 결과들을 통해 노년 집단은 단어 재인 과제에 있어서 목표단어를 예측하는 경향 이 있고, 건너뛰기 및 도약이 많다고 볼 수 있다. 따라서 본 연구과제 에서 노년 집단은 청년 집단보다 제시된 단어 자극을 예측하고 다 른 방해자극으로 시선이 빠르게 분산되어 여러 자극을 훓어봄으 로써 시선고정비율이 낮은 것으로 해석해볼 수 있다.

추가적으로 시간 구간별로 인지부하 조건에 따른 시선고정비율 에도 차이가 있었다. 구간 1 은 높은 인지부하 조건에서 시선고정비 율이 높았고, 구간5는 반대로 낮은 인지부하 조건에서 시선고정비 율이 높았다. 또한, 시간 구간에 따른 인지부하 조건 및 집단 간 시 선고정비율 차이가 유의하였다. 세부적으로 청년 집단에서는 차이 가 나타나지 않았지만, 노년 집단에서 구간2와 구간5에서 인지부 하에 따른 시선고정비율 차이가 유의하게 나타났다. 즉, 구간 2 의 경 우, 높은 인지부하 조건에서 시선고정비율이 높았고, 구간5에서는 반대로 낮은 인지부하 조건에서 시선고정비율이 높았다. 인지부하 가 시선추적에 미치는 영향에 관한 연구들에 의하면 주로 인지적 요구가 높을 때, 시선고정비율이 높아지며, 인지적 노력이 많아질 수록 활성화된 뇌 활동으로 인해 인지부하가 나타나는 것으로 알 려져 있다(Landgraf, Van der Meer, \& Krueger, 2010). 시선추적과 뇌파를 활용한 한국어 학습자의 읽기 과정에 대한 연구(Im, Min, $\&$ Cho, 2017)에 의하면 특정 자극에 고정시간이 길수록 정보처리 에 어려움을 느끼며, 어려운 읽기 요소가 포함되면 시선고정 시간 및 횟수가 증가하는 것으로 보고되고 있다(Rayner, Ashby, Pollatsek, \& Reichle, 2004). 이를 통해 앞서 높은 인지부하 조건에서는 정 보처리에 어려움을 느껴 단어가 시작되는 앞 구간에 시선고정비율 이 높게 나타난 것으로 해석해볼 수 있다. 다만, 노년 집단의 경우, 시간이 갈수록 높은 인지부하 조건에서 시선고정비율이 낮아지고 낮은 인지부하 조건에서 시선고정비율이 높았다. 이는 앞서 오프라 인 측정변수 결과에서 언급한 바와 같이, 인지부하 과제를 시간적 인 처리부담 관점에서 보았을 때, 낮은 인지부하의 경우, 짧은 시간 
내에 두 가지 과제를 처리하는 과정에서 빠른 주의전환의 어려움이 나타난 것으로 추정해볼 수 있다. 이를 통해 노인들은 시간적으로 먼저 입력된 자극에 대한 억제 기제가 청년보다 약화되어 있다고 볼 수 있다. 즉, 전반적으로 노년 집단은 청년 집단보다 복잡한 수행을 하는 과정에서 어려움을 보이게 되며(Reese \& Rodeheaver, 1985), 특히, 시간적 인지부하에 따른 주의전환 및 억제기능 약화로 인해 비효율적인 정보처리를 하는 경향이 높다고 추정해 볼 수 있다.

다만, 반응시간과 달리 시선고정비율에서 구체적으로 작업기억 용량과 상관관계가 나타나지 않은 이유는 두 가지 견해로 설명이 가능하다. 먼저 앞서 서론에서 언급된 개별 자원 모델(separated resource model, Caplan \& Waters, 1999)를 기반으로 처리하는 정보 에 따라 인지적 자원의 사용이 다르다는 주장을 통해 설명이 가능 하다. 즉, 개별 자원 모델을 통해 온라인 처리과정은 작업기억의 개 입이 최소화된다는 이론에 의해 작업기억 효과가 시선추적 측정변 수에서는 유의하지 않았을 수 있다. 또 다른 설명은 본 연구에서 사 용한 인지부하 조건이 노년층의 작업기억용량을 충분히 초과할 정 도로 과제 난이도가 높지 않았을 가능성이다. 따라서, 향후 연구는 과제 난이도를 높여 이러한 효과를 살펴볼 수 있다. 하지만, 인지부 하 조건과 집단 및 구간에 따른 삼차상호작용이 유의하였다는 점 에서 본 연구에서 사용한 인지부하 조건에 대한 조절이 노년과 청 년 집단의 온라인 처리과정에서의 차이를 살펴보기에는 충분한 난 이도였음을 알수 있다.

\section{제한점 및 종합 논의}

본 연구결과에 의하면 인지부하 조건과 집단 및 구간에 따른 상 호작용이 나타나기는 하였으나, 작업기억용량과의 영향이 명확하 게 나타나지 않았다. 이는 인지적 자원의 개입이 필요한 정도의 난 이도가 아니었을 가능성이 있음을 시사한다. 따라서 후속연구에서 는 본 연구에서 사용한 자극 제시 시간을 일정하게 하여 1 초에 숫 자 1 개 또는 숫자 4 개를 동시에 제시하는 실험 패러다임과 같이 다 양한 방식으로 난이도 조절을 통해 작업기억용량의 영향을 더 구 체적으로 확인할 수 있을 것으로 보인다. 또한, 본 연구에서는 시선 추적을 통해 노년과 청년 집단의 시선의 움직임에 대해 분석을 하 였으나, 추후 시선추적과 $\mathrm{ERP}$ 를 함께 측정하고 결과 분석을 통해 언어처리과정에 대한 심도 있는 연구가 필요할 것으로 보인다.

본 연구에서는 시선추적기법을 활용하여 작업기억용량, 인지부 하가 단어 재인에 미치는 영향에 대해 청년과 노년 집단별 특성을 파악하고자 하였다. 숫자 외우기 과제와 단어 재인 과제를 실시하 였으며, 오프라인 측정변수인 반응정확도, 반응시간, 온라인 측정 변수인 시선고정비율로 나누어 분석하였다. 연구결과, 측정변수에
따라 단어 재인 과제에서 작업기억용량, 인지부하, 집단과의 연관성 이 다르게 나타났다. 특히, 단어 재인 과정에서 반응정확도와 달리, 반응시간 또는 시선고정비율에서 집단 간 차이 이외에 작업기억용 량과 인지부하 요인과의 상호작용이 유의하였다. 이를 통해 언어처 리는 인지부하, 작업기억용량 차이와 같은 복합적인 요인이 영향을 미쳤음을 간접적으로 시사한다. 더 나아가 본 연구에서 작업기억 용량, 인지부하가 단어 재인에 미치는 영향에 대해 단순히 반응정 확도만 측정하는 것은 충분하지 않은 것으로 나타났다. 즉, 반응정 확도, 반응시간과 같은 오프라인 측정변수와 함께 온라인 측정변 수를 통해 노화, 작업기억, 인지부하와 언어처리에 대한 연관성에 관해 확인할 수 있음을 보여준다. 또한, 본 연구결과는 언어 및 인지 손상이 예상되는 성인 대상자를 위해 작업기억 손상 조기 예측 및 진단할 수 있는 방법 개발에 기초적 자료로써 기여할 수 있다고 본 다. 따라서 추후 지속적으로 작업기억용량 및 인지부하가 미치는 영향에 대해 시선추적 이외에 다양한 변수를 통한 심도 깊은 후속 연구가 필요하다.

\section{REFERENCES}

Allopenna, P. D., Magnuson, J. S., \& Tanenhaus, M. K. (1998). Tracking the time course of spoken word recognition using eye movements: evidence for continuous mapping models. Journal of Memory \& Language, 38(4), 419-439.

Amso, D., Johnson, S. P., \& Markant, J. (2014). An eye tracking investigation of developmental change in bottom-up attention orienting to faces in cluttered natural scenes. PloS One, 9(1), e85701.

Baddeley, A. D. (2000). Short-term and working memory. In E. Tulving \& F. I. M. Craik (Eds.), The Oxford handbook of memory (pp. 77-92). New York, NY:Oxford University Press.

Bae, S. B., \& Yi, K. O. (2010). Processing of orthography and phonology in Korean word recognition. The Korean Journal of Cognitive and Biological Psychology, 22(3), 369-385.

Balota, D. A., \& Duchek, J. M. (1988). Age-related differences in lexical access, spreading activation, and simple pronunciation. Psychology and Aging, 3(1), 84-93.

Bayles, K. A., Tomoeda, C. K., Kaszniak, A. W., Stern, L. Z., \& Eagans, K. K. (1985). Verbal perseveration of dementia patients. Brain and Language, 25(1), 102-116.

Ben-David, B. M., Chambers, C. G., Daneman, M., Pichora-Fuller, M. K., Reingold, E. M., \& Schneider, B. A. (2011). Effects of aging and noise on 
real-time spoken word recognition: evidence from eye movements. Journal of Speech, Language, and Hearing Research, 54(1), 243-262.

Bolden, D., Barmby, P., Raine, S., \& Gardner, M. (2015). How young children view mathematical representations: a study using eye-tracking technology. Education Research, 57(1), 59-79.

Buckner, R. L. (2013). The brain's default network: origins and implications for the study of psychosis. Dialogues in Clinical Neuroscience, 15(3), 351358.

Bundesen, C. (1990). A theory of visual attention. Psychological Review, 97(4), 523-547.

Burke, D. M., \& Peters, L. (1986). Word association in old age: evidence for consistency in semantic encoding during adulthood. Psychology and Aging, 1(4), 283-292.

Caplan, D., DeDe, G., Waters, G., Michaud, J., \& Tripodis, Y. (2011). Effects of age, speed of processing, and working memory on comprehension of sentences with relative clauses. Psychology and Aging, 26(2), 439-450.

Caplan, D., \& Waters, G. (1999). Verbal working memory and sentence comprehension. Behavioral and brain Sciences, 22(1), 77-94.

Caplan, D., \& Waters, G. (2005). The relationship between age, processing speed, working memory capacity, and language comprehension. Memory, 13(3-4), 403-413.

Carpenter, P. A., \& Just, M. A. (1989). The role of working memory in language comprehension. In D. Klahr \& K.Kotovsky(Eds), Complex information processing: The impact of Herbert A. Simon(pp.31-68). Hillsdale, NJ: Erlbuam.

Cho, M. J., Bae, J. N., Suh, G. H., Hahm, B. J., Kim, J. K., Lee, D. W., \& Kang, M. H. (1999). Validation of geriatric depression scale, Korean version (GDS) in the assessment of DSM-III-R major depression. Journal of Korean Neuropsychiatric Association, 38(1), 48-63.

Choi, W., Lowder, M. W., Ferreira, F., Swaab, T. Y., \& Henderson, J. M. (2017). Effects of word predictability and preview lexicality on eye movements during reading: a comparison between young and older adults. Psychology and Aging, 32, 232-242.

Christensen, K. J., Multhaup, K. S., Nordstrom, S. K., \& Voss, K. A. (1991). A new cognitive battery for dementia: relative severity of deficits in Alzheimer's disease. Developmental Neuropsychology, 7(4), 435-449.

Clifton, Jr. C., Ferreira, F., Henderson, J. M., Inhoff, A. W., Liversedge, S. P., Reichle, E. D., ..., \& Reichle E. D. (2016). Eye movements in reading and information processing: Keith Rayner's 40 year legacy. Journal of Memory and Language, 86, 1-19.
Cohen, G., \& Faulkner, D. (1983). Word recognition: age differences in contextual facilitation effects. British Journal of Psychology, 74(2), 239-251.

Conway, A. R. A., \& Engle, R. W. (1994). Working memory and retrieval: a resource-dependent inhibition model. Journal of Experimental Psychology: Gernal, 123(4), 354-373.

Conway, A. R. A., Tuholski, S. W., Schisler, R. J., \& Engle, R. W. (1999). The effect of memory load on negative priming: an individual differences investigation. Memmory \& Cognition, 27(6), 1042-1050.

Daneman, M., \& Merikle, P. M. (1996). Working memory and language comprehension: a meta-analysis. Psychonomic Bulletin \& Review, 3(4), 422433.

DeDe, G., Caplan, D., Kemtes, K., \& Waters, G. (2004). The relationship between age, verbal working memory, and language comprehension. Psychology and Aging, 19(4), 601-616.

Duncan, J., \& Humphreys, G. (1989). Visual search and stimulus similarity. Psychological Review, 96(3), 433-458.

Ehrlich, S. F., \& Rayner, K. (1981). Contextual effects on word perception and eye movements during reading. Journal of Verbal Learning and Verbal Behavior, 20(6), 641-655.

Eom, B. R., Oh, S. J., \& Sung, J. E. (2016). Task-specific effects on performance of working memory measures and their relationship to aphasia severity in people with aphasia. Journal of Speech-Language \& Hearing Disorders, 25(2), 113-122.

Feyereisen, P. (1997). A meta-analytic procedure shows age-related decline in picture naming: comments on Goulet, Ska, \& Kahn (1994). Journal of Speech and Hearing Research, 40(6), 1328-1333.

Geva, R., Zivan, M., Warsha, A., \& Olchik, D. (2013). Alerting, orienting or executive attention networks: differential patters of pupil dilations. Frontiers in Behavioral Neuroscience, 7, 145.

Giaquinto, S., Ranghi, F., \& Butler, S. (2007). Stability of word comprehension with age: an electrophysiological study. Mechanisms of Ageing and Development, 128(11-12), 628-636.

Hadar, B., Skrzypek, J. E., Wingfield, A., \& Ben-David, B. M. (2016). Working memory load affects processing time in spoken word recognition: evidence from eye-movements. Frontiers in Neuroscience, 10, 221.

Hasher, L., \& Zacks, R. T. (1988). Working memory, comprehension, and aging: a review and a new view. Psychology of Learning and Motivation. 22, 193-225.

Honey, G. D., Bullmore, E. T., \& Sharma, T. (2000). Prolonged reaction time to a verbal working memory task predicts increased power of posterior 
parietal cortical activation. NeuroImage, 12(5), 495-503.

Howard, D. V., Shaw, R. J., \& Heisey, J. G. (1986). Aging and the time course of semantic activation. Journal of Gerontology, 41(2), 195-203.

Huang, P. S., \& Chen, H. C. (2015). Gender differences in eye movements in solving text-and-diagram science problems. International Journal of Science and Mathematics Education, 14(2), 327-346.

Hultsch, D. F., Hertzog, C., \& Dixon, R. A. (1990). Ability correlates of memory performance in adulthood and aging. Psychology and Aging, 5(3), 356368.

Humes, L. E. (2020). What is "normal hearing" for older adults and can "normal-hearing older adults" benefit from hearing care intervention. Hearing Review, 27(7), 12-18.

Hwang, S., Kim, J., Park, K., Chey, J., Hong, S. (2012). Korean Wechsler Adult Intelligence Scale-IV. Daegu: Korea Psychology.

Im, J. N., Min, S. N., \& Cho, S. M. (2017). Analysis of reading process with Korean learner using EEG and eye tracking. Journal of the Ergonomics Society of Korea, 36(6), 717-727.

Jeong, H. S., \& Pyun, J. Y. (2005). Recall and interpretation of narrative texts in college students, middle-aged, and older adults groups. The Korean Journal of Experimental Psychology, 17(4), 509-527.

Jo, H. L., \& Sung, J. E. (2019). Age-related differences in word recognition task according to the Interference types: evidence from eye-tracking. Communication Sciences \& Disorders, 24(1) 186-204.

Johnson, M. K., \& Raye, C. L. (1998). False memories and confabulation. Trends in Cognitive Sciences, 2(4), 137-145.

Joo, Y., \& Jang, H. (2009). Effects of frequency range and degree of hearing Loss on word recognition in elderly listeners. Audiology and Speech Research, 5(1), 36-41.

Just, M. A., \& Carpenter, P. A. (1992). A capacity theory of comprehension: individual differences in working memory. Psychological Review, 99(1), 122-149.

Kang, S. I. N. (2007). Phonological awareness and word recognition characteristic in Down syndrome (Master's thesis). Dankook University, Gyeonggi, Korea.

Kang, Y. (2006). A normative study of the Korean-Mini Mental State Examination (K-MMSE) in the elderly. Korean Journal of Psychology: General, 25(2), 1-12.

Kang, Y., \& Na, D. L. (2003). Seoul neuropsychological screening battery. Seoul: Human Brain Research \& Consulting Co.

Kang, Y., Na, D. L., \& Hahn, S. (1997). A validity study on the Korean Mini-
Mental State Examination (K-MMSE) in dementia patients. Journal of the Korean Neurological Association, 15(2), 300-308.

Kim, O. H., Choi, S., \& Hwang, M. (2016). Semantic interference effect in picture-word naming tasks between youth and elderly. Communication Sciences \& Disorders, 21(3), 462-471.

Kim, Y. B., Sung, J. E., \& Kim, Y. H. (2013). Verbal and non-verbal working memory capacity and its relation to sentence comprehension in aphasia. Journal of Speech-Language \& Hearing Disorders 22(1), 1-16.

Kliegl, R., Grabner, E., Rolfs, M., \& Engbert, R. (2004). Length, frequency, and predictability effects of words on eye movements in reading. European Journal of Cognitive Psychology, 16(1-2), 262-284.

Landgraf, S., Van der Meer, E., \& Krueger, F. (2010). Cognitive resource allocation for neural activity underlying mathematical cognition: a multimethod study. ZDM Mathematics Education, 42(6), 579-590.

Lee, H. S. (2005). Is the memory function in old adults really impaired?. Korean Journal of Clinical Psychology, 24(3), 581-598.

Lee, H. S., Ahn, C. Y., \& Jung, I. K. (1999). A preliminary study on standardization of K-MAS (Korean version of Memory Assessment Scales). Korean Journal of Clinical Psychology, 18(1), 221-241.

Lee, H. W., Kim, S. K., Lee, K. E., Chung, E. J., \& Park, J. Y. (2012). The agerelated changes in cognitive function. The Korean Journal of Cognitive and Biological Psychology, 24(2), 127-148.

Lee, M. S., \& Kim, H. H. (2012). Cognitive-pragmatic language assessment for normal aging: study of assessment tools and content validity. The Journal of the Korea Contents Association, 12(5), 280-292.

Lee, S. J., Lee, S. J., Song, J. Y., \& Kim, H. (2014). Characteristics of language comprehension in normal elderly and the mild cognitive impaired. Dementia and Neurocognitive Disorders, 13(3), 51-62.

Madden, D. J. (1988). Adult age differences in the effects of sentence context and stimulus degradation during visual word recognition. Psychology and Aging, 3(2), 167-172.

Miyake, A., Just, M. A., \& Carpenter, P. A. (1994). Working memory constraints on the resolution of lexical ambiguity: Maintaining multiple interpretations in neutral contexts. Journal of Memory and Language; New York, 33(2), 175-202.

Montgomery, J. W., \& Evans, J. L. (2009). Complex sentence comprehension and working memory in children with specific language impairment. Journal of Speech and Hearing Research, 52(2), 269-288.

National Institute of Korean Language. (2015). Survey on the frequency of Korean use. Seoul, Author. 
Nicholas, M., Barth, C., Obler, L. K., Au, R., \& Albert, M. L. (1997). Naming in normal aging and demetia of the Alzheimer's type. In H. Goodglass \& A. Wingfield (Eds.), Anomia: Neuroanatomical and cognitive correlates (pp. 17-188). New York: Academic Press.

Nitsan, G., Wingfield, A., Lavie, L., \& Ben-David, B. M. (2019). Differences in working memory capacity affect online spoken word recognition: evidence from eye movements. Trends in Hearing, 23, 1-12.

Park, S., \& Whang, M. (2018) Infrared camera-based non-contact measurement of brain activity from pupillary rhythms. Front Physiol, 9, 1400.

Parker, A., Relph, S., \& Dagnall, N. (2008). Effects of bilateral eye movements on the retrieval of item, associative, and contextual information. Neuropsychology, 22(1), 136-145.

Portrat, S., Barrouillet, P., \& Camos, V. (2008). Time-related decay or interference-based forgetting in working memory?. Journal of Experimental Psychology: Learning, Memory, and Cognition, 34(6). 1561-1564.

Ramsay, C. B., Nicholas, M., Au, R., Olber, L. K., \& Albert, M. L. (1999). Verb naming in normal aging. Applied Neuropsychology, 6(2), 57-67.

Rayner, K. (1998). Eye movements in reading and information processing: 20 years of research. Psychological Bulletin, 124(3), 372-422.

Rayner, K. (2009). Eye movements and attention in reading, scene perception, and visual search. The Quarterly Journal of Experimental Psychology, 62(8), 1457-1506.

Rayner, K., Ashby, J., Pollatsek, A., \& Reichle, E. D. (2004). The effects of frequency and predictability on eye fixations in reading: implications for the EZ Reader model. Journal of Experimental Psychology: Human Perception and Performance, 30(4), 720-732.

Rayner, K., Reichle, E. D., Stroud, M. J., Williams, C. C., \& Pollatsek, A. (2006). The effect of word frequency, word predictability, and font difficulty on the eye movements of young and older readers. Psychology and Aging, 21(3), 448-465.

Reese, H. W., \& Rodeheaver, D. (1985). Problem solving and complex decision making. In J.E. Birren \& K. W. Schaie (Eds.), Handbook of the psychology of aging (pp. 474-499), New York: Van Nostrand Reinhold Co.

Thornton, R., \& Light, L. L. (2006). Language comprehension and production in normal aging. In J.E. Birren, \& K.W. Schaie (Eds.), Handbook of the Psychology of Aging (6th ed., pp. 261-287). Amsterdam, The Netherlands: Elsevier.

Salthouse, T. A. (1990). Working memory as a processing resource in cognitive aging. Developmental Review, 10(1), 101-124.

Salthouse, T. A., \& Babcock, R. L. (1991). Decomposing adult age differences in working memory. Developmental Psychology, 27(5), 763-776.

Sass, S. M., Legge, G. E., \& Lee, H. (2006). Low-vision reading speed: influence of linguistic inference and aging. Optometry and Vision Science, 83(3), 166-177.

Schmitter-Edgecombe, M., Vesneski, M., \& Jones, D. W. R. (2000). Aging and word-finding: a comparison of spontaneous and constrained naming tests. Archives of Clinical Neuropsychology, 15(6), 479-493.

Speranza, F., Daneman, M., \& Schneider, B. A. (2000). How aging affects the reading of words in noisy backgrounds. Psychology and Aging, 15(2), 253258.

Spieler, D. H., \& Balota, D. A. (2000). Factors influencing word naming in younger and older adults. Psychology and Aging, 15(2), 225-231.

Stark, R., Mandl, H., Gruber, H., \& Renkl, A. (2002). Conditions and effects of example elaboration. Learning and Instruction, 12, 39-60.

Stine-Morrow, E. A., Miller, L. M. S., Gagne, D. D., \& Hertzog, C. (2008). Self-regulated reading in adulthood. Psychology and Aging, 23(1), 131-153. Stine-Morrow, E. A., Miller, L. M. S., \& Nevin, J. A. (1999). The effects of context and feedback on age differences in spoken word recognition. The Journals of Gerontology Series B: Psychological Sciences and Social Sciences, 54(2), 125-134.

Stine-Morrow, E. A., Noh, S. R., \& Shake, M. C. (2010). Age differences in the effects of conceptual integration training on resource allocation in sentence processing. The Quarterly Journal of Experimental Psychology, 63(7), 1430-1455.

Sung, J. E. (2011). The reliability and validity of short-term and working memory pointing tasks developed for clinical populations with speech and language disorders. Korean Journal of Communication Disorders, 16(2), 185-201.

Sung, J. E., Mo, K. O., Lee, J. S., \& Sim, H. S. (2014). Production frequency, semantic typicality, and familiarity of noun exemplars for elderly adults. Communication Sciences and Disorders, 19(2), 213-225.

Susac, A. N. A., Bubic, A., Kaponja, J., Planinic, M., \& Palmovic, M. (2014). Eye movements reveal students' strategies in simple equation solving. International Journal of Science and Mathematics Education, 12(3), 555-577.

Tak, H. I., Sung, J. E., Jeong, J. H., \& Kim, G. H. (2016). The effect of processing load on semantic and phonological working memory in mild cognitive impairment. Communication Sciences \& Disorders, 21(2), 295-309.

Tark, K. J., \& Kim, M. S. (2005a). The effects of working memory on visual marking. Proceedings of the Korean Psychological Association, 332-333.

Tark, K. J., \& Kim, M. S. (2005b). Visual Marking is Independent of Working 
Memory. The Korean Journal of Cognitive and Biological Psychology, 17(4), 389-408.

Thompson, C. K., \& Choy, J. J. (2009). Pronominal resolution and gap filling in agrammatic aphasia: evidence from eye movements. Journal of Psycholinguistic Research, 38(3), 255-283.

Treisman, A., \& Gelade, G. (1980). A feature integration theory of attention. Cognitive Psychology, 12(1), 97-136.

Van Steenbergen, H., \& Band, G. P. (2013). Pupil dilation in the Simon task as a marker of conflict processing. Frontiers in Human Neuroscience, 7 , 215.

Wassenaar, M., \& Hagoort, P. (2007). Thematic role assignment in patients with Broca's aphasia: sentence-picture matching electrified. Neuropsycho$\operatorname{logia}, 45(4), 716-740$.
Waters, G. S., \& Caplan, D. (2001). Age, working memory, and on-line syntactic processing in sentence comprehension. Psychology and Aging, 16(1), 128-144.

Yang, S. H., Lee, H. J., \& Park, S. J. (2020). Literature review on language reception and expression ability related to aging. Journal of Speech-Language \& Hearing Disorders, 29(1), 49-57.

Yeon, E. J., Cho, E. B., Lee, S. J., Kim, S. W., Lee, Y., \& Yoon, J. H. (2017). Characteristics of word reading according to word condition in normal adults. Communication Sciences \& Disorders, 22(4), 730-744.

Yoo, H., Lee, J. M., \& Do, K. S. (2005). Age differences in integrating multiple sources of information in working memory. Journal of the Korean Gerontological Society, 25(4), 115-129. 
Appendix 1. 실험자극 단어목록

\begin{tabular}{|c|c|c|c|c|}
\hline 범주 & 목표어휘 & 음운적 관련어휘 & 의미적 관련어휘 & 무관련어휘 \\
\hline 과일 & 수박 & 수갑 & 체리 & 가마 \\
\hline 과일 & 참외 & 참치 & 석류 & 드럼 \\
\hline 과일 & 사과 & 사슴 & 키위 & 눈썹 \\
\hline 과일 & 망고 & 망토 & 딸기 & 오리 \\
\hline 과일 & 포도 & 포크 & 멜론 & 새우 \\
\hline 과일 & 대추 & 대포 & 자두 & 연필 \\
\hline 과일 & 바나나 & 바둑판 & 무화과 & 청소기 \\
\hline 과일 & 오렌지 & 오징어 & 복숭아 & 세탁기 \\
\hline 교통수단 & 지하철 & 지우개 & 돛단배 & 항아리 \\
\hline 교통수단 & 리어카 & 리모컨 & 지게차 & 병아리 \\
\hline 교통수단 & 비행기 & 비키니 & 유모차 & 가야금 \\
\hline 교통수단 & 자전거 & 자판기 & 굴착기 & 독수리 \\
\hline 교통수단 & 버스 & 버선 & 요트 & 휴지 \\
\hline 교통수단 & 마차 & 마늘 & 택시 & 플룻 \\
\hline 교통수단 & 기차 & 기타 & 탱크 & 호스 \\
\hline 교통수단 & 소방차 & 소나무 & 보행기 & 탬버린 \\
\hline 네발동물 & 기린 & 기둥 & 염소 & 배추 \\
\hline 네발동물 & 사자 & 사탕 & 돼지 & 당근 \\
\hline 네발동물 & 치타 & 치즈 & 늑대 & 향수 \\
\hline 네발동물 & 고양이 & 고구마 & 얼룩말 & 빗자루 \\
\hline 네발동물 & 다람쥐 & 다리미 & 코끼리 & 선인장 \\
\hline 네발동물 & 강아지 & 강낭콩 & 호랑이 & 실로폰 \\
\hline 네발동물 & 하마 & 하프 & 토끼 & 버섯 \\
\hline 네발동물 & 낙타 & 낙지 & 여우 & 달력 \\
\hline 생활용품 & 도마 & 도넛 & 밥솥 & 장구 \\
\hline 생활용품 & 화장품 & 화살표 & 냉장고 & 부엉이 \\
\hline 생활용품 & 국자 & 국화 & 망치 & 스키 \\
\hline 생활용품 & 거울 & 거미 & 칫솔 & 오이 \\
\hline 생활용품 & 주전자 & 주사위 & 숟가락 & 토마토 \\
\hline 생활용품 & 그릇 & 그네 & 책상 & 호두 \\
\hline 생활용품 & 수건 & 수염 & 비누 & 문어 \\
\hline 생활용품 & 바가지 & 바게트 & 전화기 & 색소폰 \\
\hline 옷 & 장갑 & 장미 & 양말 & 볼펜 \\
\hline 옷 & 치마 & 치약 & 재킷 & 트럭 \\
\hline 옷 & 가운 & 가지 & 장화 & 의자 \\
\hline 옷 & 모자 & 모기 & 한복 & 입술 \\
\hline 옷 & 양복 & 양파 & 잠옷 & 타조 \\
\hline 옷 & 원피스 & 원숭이 & 긴바지 & 피아노 \\
\hline 옷 & 반바지 & 반창고 & 슬리퍼 & 샤워기 \\
\hline 옷 & 조끼 & 조개 & 팬티 & 신문 \\
\hline
\end{tabular}




\section{국문초록}

\section{작업기억용량 및 인지부하가 단어 재인에 미치는 영향에 대한 청년과 노년 집단 간 수행비교: 시선추적 연구}

유민아 ${ }^{1} \cdot$ 오승하 ${ }^{2}$ · 경정숙 ${ }^{3}$ 성지은 ${ }^{1}$

${ }^{1}$ 이화여자대학교 대학원 언어병리학과, ${ }^{2}$ 서울대학교 의과대학 이비인후과, ${ }^{3}$ 한림국제대학원대학교 청각언어치료학과

배경 및 목적: 본 연구는 청년과 노년을 대상으로 작업기억용량과 인지부하 정도의 차이가 단어 재인 능력에 미치는 영향에 대해 시선 추적기법을 통해 알아보고자 하였다. 방법: 청년과 노년 집단별로 24 명씩, 총 48 명이 본 실험에 참여하였으며, 세부적으로 각 집단 내에 서 작업기억용량(고, 저) 집단으로 분류하였다. 본 연구는 인지부하 조건(고, 저)인 숫자 외우기 과제와 단어 재인 과제를 실시하였다. 본 연구의 결과에 대해 오프라인 측정변수인 반응정확도, 반응시간, 온라인 측정변수인 시선고정비율로 나누어 분석하였다. 결과: 반응정 확도 및 반응시간의 경우, 단어 재인 과제에서 청년 및 노년 집단 간 주효과가 유의하였다. 추가로 반응시간의 경우, 작업기억용량에 따 른 인지부하 조건 간 이차상호작용이 유의하였다. 시선고정비율의 경우, 집단 간 주효과가 유의하였다. 또한, 시간 구간에 따른 집단 간, 인지부하 조건 간 이차상호작용이 유의하였으며, 시간 구간별 인지부하 조건 및 집단 간 삼차상호작용도 유의하였다. 논의 및 결론: 반 응정확도와 달리 반응시간, 시선고정비율은 집단 간 차이 이외에 인지부하, 작업기억용량 요인과의 상호작용효과가 유의하였다. 이를 통해 언어처리는 인지부하, 작업기억용량 같은 복합적인 요인이 영향을 미쳤음을 간접적으로 시사한다. 더 나아가 언어 처리과정에 대 해 반응정확도 측정만으로는 충분하지 않다. 따라서 오프라인 측정변수와 함께 온라인 측정변수를 통해 노화, 작업기억용량, 인지부하 조건과 단어 재인 능력에 대한 연관성을 확인할 수 있음을 보여준다.

핵심어: 작업기억용량, 인지부하, 노화, 단어 재인, 시선추적기법

본 연구는 대한민국 교육부와 한국연구 재단의 지원을 받아 수행된 연구임(No. NRF-2019R1A2C1089280).

\section{참고문헌}

국립국어원 (2015). 한국어 사용빈도 조사. 서울: 국립국어원.

강샘이나 (2007). 다운 증후군 집단의 음운인식 특성과 단어재인 특성 연구. 석사학위청구논문. 단국대학교 대학원.

강연욱 (2006). K-MMSE(Korean-Mini Mental State Examination)의 노인 규준 연구. 한국심리학회지, 25(2), 1-12.

강연욱, 나덕렬(2003). 서울신경심리검사(Seoul Neuropsychological Screening Battery). 서울: 휴브알엔씨.

강연욱, 나덕렬, 한승혜 (1997). 치매 환자들을 대상으로 한 K-MMSE의 타당도 연구. 대한신경과학회지, 15(2), 300-308.

김오현, 최소영, 황민아 (2016). 그림이름대기에서 나타난 청년층과 노년층의 의미간섭효과. Communication Sciences \& Disorders, 21(3), 462-471.

김유빈, 성지은, 김연희 (2013). 구어 및 비구어 작업기억용량과 실어증 환자의 문장이해 능력 간의 상관. 언어치료연구, 22(1), 1-16.

배성봉, 이광오 (2010). 한국어 단어 재인에서 표기 음절과 음운음절의 처리. 한국심리학회지: 인지 및 생물, 22(3), 369-385.

성지은 (2011). 말언어장애군의 단기기억 및 작업기억용량 측정을 위한 지시하기과제 개발 예비 연구: 재검사 신뢰도 및 타당도. 언어청각장애연구,

16(2), 185-201.

성지은, 모경옥, 이지선, 심현섭(2014). 노년층을 대상으로 한 명사 범주별 본보기 산출빈도, 의미전형성 및 친숙도 연구. Communication Sciences \&

Disorders, 19(2), 213-225.

양송희, 이현주, 박성지 (2020). 노화와 관련된 언어이해력 및 언어표현력 문헌연구. 언어치료연구, 29(1),49-57.

엄보라, 오세진, 성지은 (2016). 자극 유형과 반응 순서에 따른 실어증 환자의 작업기억 수행력 차이 및 중증도 관련 예측요인. 언어치료연구, 25(2),

113-122.

연은주, 조은별, 이수정, 김선우, 이윤경, 윤지혜(2017). 정상 성인의 단어 조건에 따른 읽기 특성. Communication Sciences \& Disorders, 22(4), 730-

744. 
유현주, 이정모, 도경수 (2005). 노인집단의 다중 정보 통합과정에 대한 연구. 한국노년학회, 25(4), 115-129.

이미숙, 김향희 (2012). 노년층의 인지-화용언어 능력 평가: 평가도구 및 내용타당도 연구. 한국콘텐츠학회논문지, 12(5), 280-292.

이수정, 이승진, 송지연, 김향희 (2014). 정상 노년층과 경도인지장애의 언어 이해력 특성. Dementia Neurocognitive Disorders, 13(3), 51-62.

이현수 (2005). 노인의 기억은 정말로 떨어지는가? Korean Journal of Clinical Psychology, 24(3), 581-598.

이현수, 안창일, 정인과 (1999). K-MAS (Korean version of Memory Assessment Scales) 표준화 예비 연구. Korean Journal of Clinical Psychology,

18(1), 221-241.

이혜원, 김선경, 이고은, 정유진, 박지윤 (2012). 연령에 따른 인지 변화양상. 한국심리학회지: 인지 및 생물, 24(2), 127-148.

임정남, 민승남, 조성문 (2017). 시선추적과 뇌파를 활용한 한국어 학습자의 읽기 과정 분석. 대한인간공학회지, 36(6), 717-727.

정혜선, 편지영 (2005). 대학생, 중년, 노인 집단의 이야기에 대한 기억과 해석. 한국심리학회지: 인지 및 생물, 17(4), 509-527.

조맹제, 배재남, 서국희, 함봉진, 김장규, 이동우, 강민희 (1999). DSM-III-R 주요 우울증에 대한 한국어판 Geriatric Depression Scale (GDS)의 진단적

타당성 연구. 대한신경정신의학회, 38(1), 48-63.

조혜련, 성지은 (2019). 시선추적을 활용한 방해자극 유형에 따른 단어재인 과제에서 청년층과 노년층 간 수행력 비교. Communication Sciences \&

Disorders, 24(1) 186-204.

주연미, 장현숙 (2009). 노인성 난청의 청력손실 정도에 따른 어음인지능력. 한국청각언어재활학회, 5(1), 36-41.

탁경진, 김민식 (2005a). 작업기억이 시각적 표시에 미치는 영향: 한국심리학회 학술대회 자료집, 332-333.

탁경진, 김민식 (2005b). 시각적 표시와작업기억 간의 독립성. 한국심리학회지: 인지 및 생물, 17(4), 389-408.

탁혜인, 성지은, 정지향, 김건하 (2016). 경도인지장애군에서 처리부담조건이 의미 및 음운 작업기억에 미치는 영향. Communication Sciences \& Dis-

orders, 21(2), 295-309.

황순택, 김지혜, 박광배, 최진영, 홍상황 (2012). K-WAIS-IV 실시 및 채점 요강. 대구: 한국심리주식회사.

\section{ORCID}

유민아(제1저자, 대학원생 https://orcid.org/0000-0002-4210-5391); 오승하(공동저자, 교수 https://orcid.org/0000-0003-1284-5070);

경정숙(공동저자, 교수 https://orcid.org/0000-0003-0798-0059); 성지은(교신저자, 교수 https://orcid.org/0000-0002-1734-0058) 